U.S. Department of the Interior

U.S. Geological Survey

Microbiological Quality of Water

From Noncommunity Supply Wells

in Carbonate and Crystalline Aquifers

of Pennsylvania

Water-Resources Investigations Report 01-4268
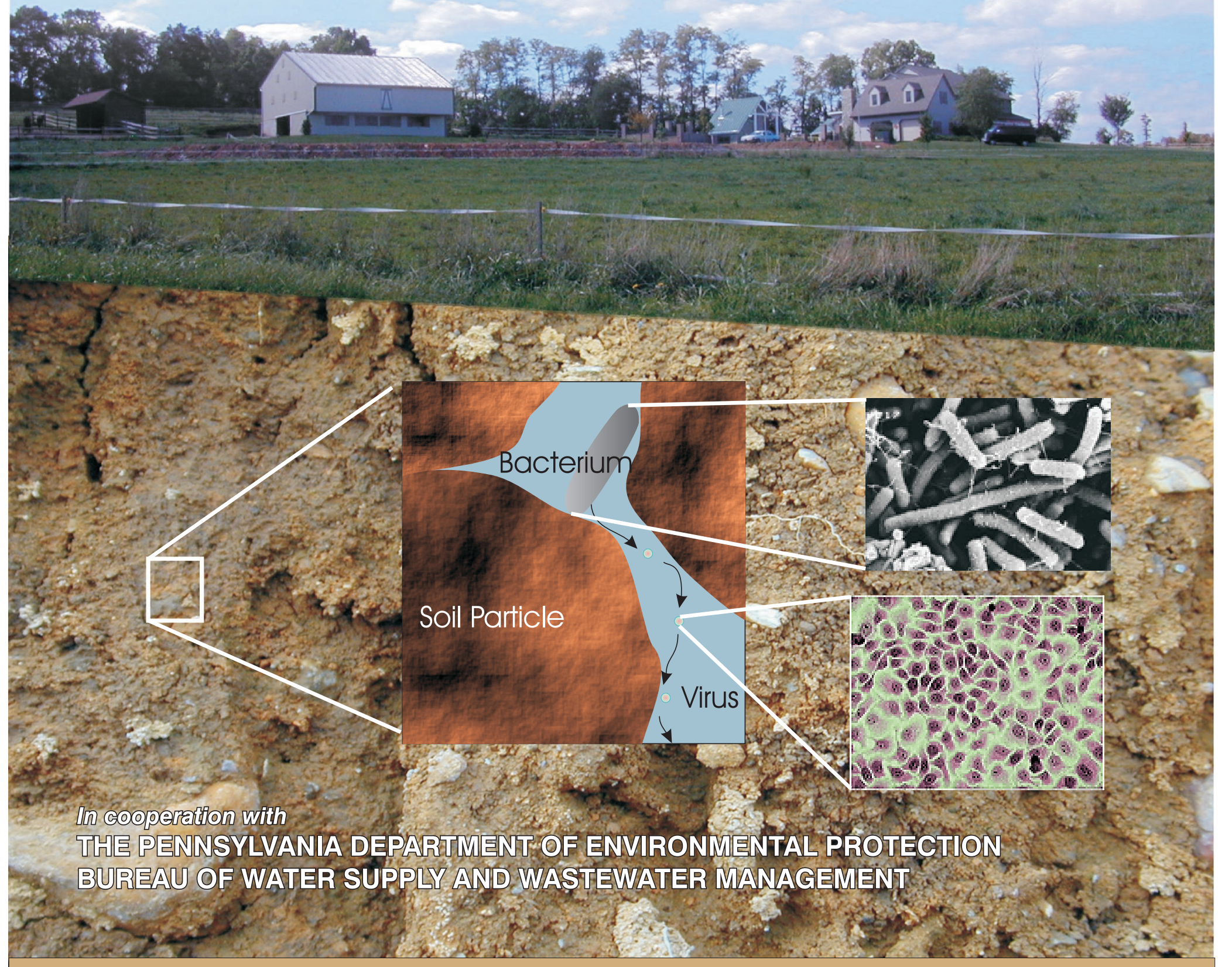

\title{
₹USGS
}

science for a changing world 
Scanning electron micrograph of Escherichia coli cells with phage particles (which appear as small white dots) attached to the outside of cells.

(C) Scott Kachlany, author, and used with permission. Licensed for use, ASM MicrobeLibrary (linked to http://www.microbelibrary.org).

Viral Cytopathic Effect in Cell Culture: Poliovirus

(C) Maria-Lucia Rácz, Institute of Biomedical Sciences, University of São Paulo, São Paulo, Brazil, and used with permission. Licensed for use, ASM MicrobeLibrary (linked to http://www.microbelibrary.org). 
U.S. Department of the Interior

U.S. Geological Survey

\section{Microbiological Quality of Water From Noncommunity Supply Wells in Carbonate and Crystalline Aquifers of Pennsylvania}

by Bruce D. Lindsey, Jennifer S. Rasberry, and Tammy M. Zimmerman

Water-Resources Investigations Report 01-4268

In cooperation with

THE PENNSYLVANIA DEPARTMENT OF ENVIRONMENTAL PROTECTION BUREAU OF WATER SUPPLY AND WASTEWATER MANAGEMENT 


\section{U.S. DEPARTMENT OF THE INTERIOR \\ GALE A. NORTON, Secretary}

U.S. GEOLOGICAL SURVEY

Charles Groat, Director

Use of firm trade and brand names in this report is for identification purposes only and does not constitute endorsement by the U.S. Government.

For additional information write to:

District Chief

U.S. Geological Survey 215 Limekiln Road

New Cumberland, Pennsylvania 17070-2424 Email: dc_pa@usgs.gov

Internet Address: http://pa.water.usgs.gov
Copies of this report may be purchased from:

U.S. Geological Survey

Branch of Information Services

Box 25286

Denver, Colorado 80225-0286

Telephone: 1-888-ASK-USGS 


\section{CONTENTS}

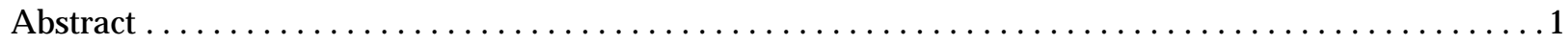

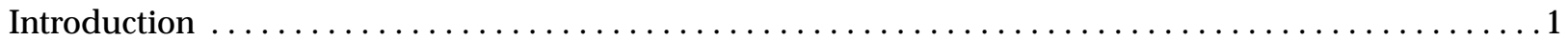

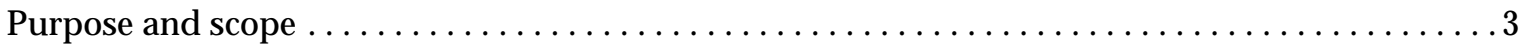

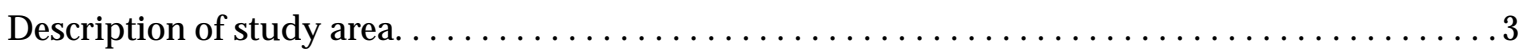

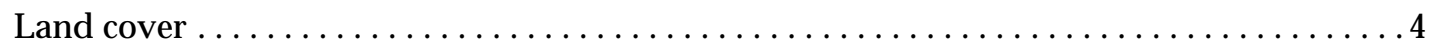

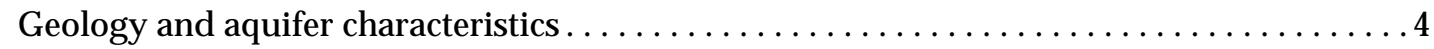

Noncommunity supply wells and the ground water rule $\ldots \ldots \ldots \ldots \ldots \ldots \ldots \ldots \ldots \ldots \ldots \ldots \ldots \ldots \ldots$

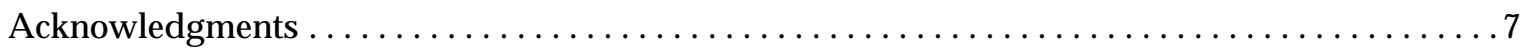

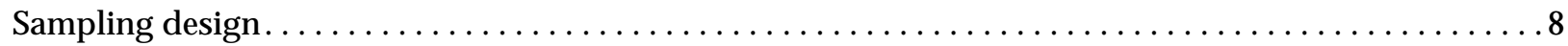

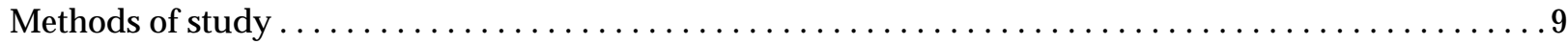

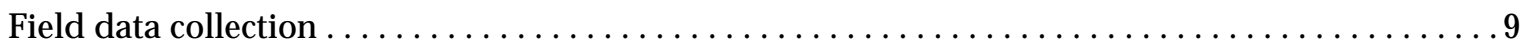

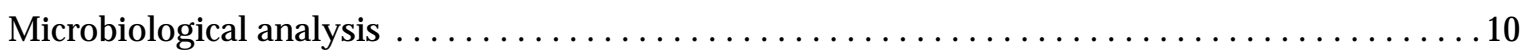

Statistical analysis............................................. 11

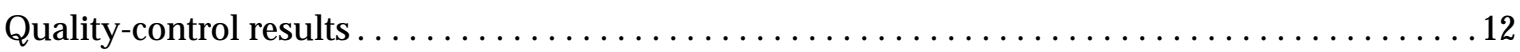

Microbiological quality of ground water used for noncommunity water supply $\ldots \ldots \ldots \ldots \ldots 13$

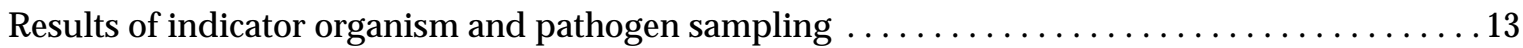

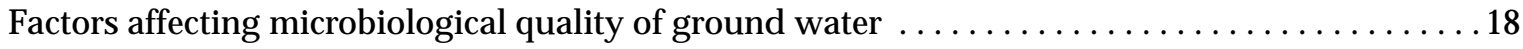

Relations between indictor bacteria and pathogens in ground water $\ldots \ldots \ldots \ldots \ldots \ldots \ldots \ldots \ldots \ldots$

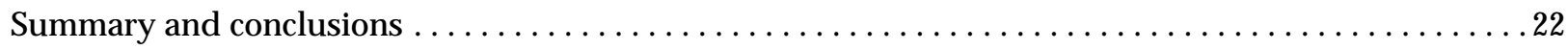

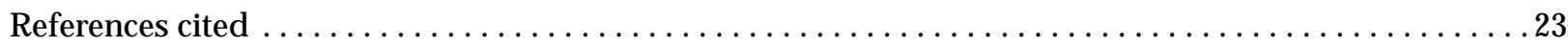

Appendix 1. Noncommunity supply well information for Pennsylvania. . . . . . . . . . . ...26

Appendix 2. Water-quality data for noncommunity supply wells in Pennsylvania . . . . . . . . . 28

CONTENTS 


\section{ILLUSTRATIONS}

Figures 1-3. Maps showing:

1. Aquifer types in Pennsylvania .............................. 3

2. Land covers in Pennsylvania ............................... 5

3. Locations of transient noncommunity supply wells in Pennsylvania . . . . . . . 7 4-11. Sampling locations and detections of:

4. Viruses in noncommunity supply wells in Pennsylvania . . . . . . . . . . . 14

5. Helicobacter pylori in noncommunity supply wells in Pennsylvania . . . . . . . . 15

6. Escherichia coli in noncommunity supply wells in Pennsylvania . . . . . . . . 15

7. Total coliform in noncommunity supply wells in Pennsylvania $\ldots \ldots \ldots \ldots \ldots$

8. Clostridium perfringens in noncommunity supply wells in Pennsylvania . . . . . 16

9. Somatic coliphage in noncommunity supply wells in Pennsylvania. . . . . . . . 17

10. Male-specific coliphage in noncommunity supply wells in Pennsylvania . . . . . 17

11. Enterococcus in noncommunity supply wells in Pennsylvania . . . . . . . . . 18

\section{TABLES}

1. Number and density of noncommunity supply wells in Pennsylvania by aquifer

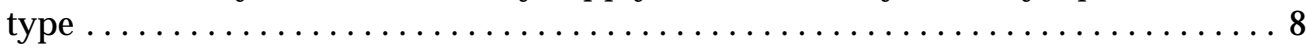

2. Microbiological organisms analyzed in the study $\ldots \ldots \ldots \ldots \ldots \ldots \ldots \ldots \ldots \ldots \ldots \ldots \ldots \ldots \ldots \ldots$

3. Sample contingency table matrix for comparison of pathogens and indicator

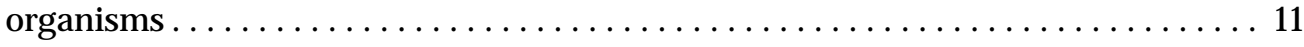

4. Comparison of replicate samples for bacteria using membrane filtration method and most probable number method for noncommunity supply wells in

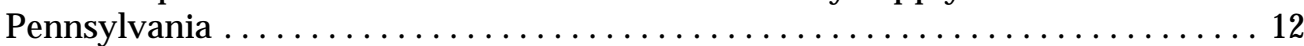

5. Number of detections of pathogens and indicator organisms by aquifer type for noncommunity supply wells in Pennsylvania.. ..................... 18

6. Summary statistics of land cover in a 1,500-foot radius of noncommunity supply wells in Pennsylvania categorized by detections and nondetections of organisms and results of logistic regression comparing occurrence of pathogens and indicator organisms among land covers within a 1,500-foot radius of the wells. . . 19

7. Results of logistic regression comparing occurrence of pathogens and indicator organisms to well depths for noncommunity supply wells in Pennsylvania . . . . 20

8. Co-occurrence of indicator organisms and pathogens for noncommunity supply wells in Pennsylvania.................................... 21 


\section{CONVERSION FACTORS AND ABBREVIATIONS}

Multiply

foot $(\mathrm{ft})$

square mile $\left(\mathrm{mi}^{2}\right)$

gallon (gal)

degree Fahrenheit $\left({ }^{\circ} \mathrm{F}\right)$
By

Length

0.3048

Area

2.590

Volume

3.785

Temperature

${ }^{\circ} \mathrm{C}=5 / 9 \times\left({ }^{\circ} \mathrm{F}-32\right)$
To obtain

meter

square kilometer

liter

degree Celsius $\left({ }^{\circ} \mathrm{C}\right)$ 



\title{
Microbiological Quality of Water from Noncommunity Supply Wells in Carbonate and Crystalline Aquifers of Pennsylvania
}

\author{
by Bruce D. Lindsey, Jennifer S. Rasberry, and Tammy M. Zimmerman
}

\begin{abstract}
Samples were collected from 59 noncommunity water supplies in the Commonwealth of Pennsylvania from September 2000 to January 2001 and analyzed for pathogens and microbiological indicator organisms. The pathogens sampled were culturable viruses and Helicobacter pylori (H. pylori). The indicator organisms sampled were total coliform, Escherichia coli (E. coli), Clostridium perfringens ( $C$. perfringens), somatic coliphage, male- specific coliphage, and enterococcus. The two primary areas sampled for the project completed by the U.S. Geological Survey, in cooperation with the Pennsylvania Department of Environmental Protection (PaDEP), were carbonate aquifers and crystalline aquifers. The results of all sampling showed culturable viruses were detected in 8 percent of the wells, H. pylori in 7 percent of the wells, E. coli in 12 percent of the wells, total coliform in 46 percent of the wells, $C$. perfringens in 15 percent of the wells, somatic coliphage in 8 percent of the wells, male-specific coliphage in 5 percent of the wells, and enterococcus in 14 percent of the wells. Carbonate aquifers tended to have higher detection rates for the pathogens and indicators sampled than the crystalline aquifers. Detections of the pathogens and indicator organisms were not related statistically to the amounts of urban, agricultural, or forested area in a 1,500 -foot radius around the sampled well. Somatic and male-specific coliphage showed the best relation to occurrence of culturable viruses. Culturable viruses and $H$. pylori were detected in wells in which no indicator organisms were present; therefore, none of the indicator organisms sampled provide complete assurance of pathogenfree water. The best predictive tool for virus screening was a combination of indicator organisms.
\end{abstract}

\section{INTRODUCTION}

The U.S. Environmental Protection Agency (USEPA) currently (2001) is developing the Ground Water Rule to protect users of public ground-water supplies from consuming water from sources affected by viral contamination. Many ground-water suppliers, especially noncommunity water suppliers, have minimal water-treatment facilities that may not be adequate for removal of viruses. Treatment processes based on bacteriological criteria do not necessarily protect against viral infection because viruses generally are more persistent in the environment and are not removed as completely by treatment processesincluding chlorination (Gerba, 1984). Up to 65 percent of outbreaks of waterborne diseases in the United States could be attributed to viruses in drinking water (Keswick and Gerba, 1980). Fecal indicator bacteria are larger than viruses and have different transport properties in the environment under certain conditions. These differences may make bacteria less than adequate screening tools for viruses.

Bickford and others (1996) determined that Escherichia coli (E. coli) was detected in about 30 percent of the wells sampled in south-central Pennsylvania. That study also showed total coliform bacteria were detected in about 70 percent of those wells. As a follow-up to the work of Bickford and others (1996), this study was conducted to assess the occurrence and distribution of pathogens and indicator organisms in ground water. The study is a cooperative effort of the U.S. Geological Survey (USGS) and the Pennsylvania Department of Environmental Protection (PaDEP) Bureau of Water Supply and Wastewater Management.

Water-borne pathogens (disease causing organisms) commonly travel the fecal-oral route of transmission. Fecal-oral transmission includes any mechanism by which individuals can ingest contaminated organisms. However, with regard to water this means that organisms originate and propagate in the intestinal tract of a host, are shed 
in fecal matter, and enter a water body used as a recreational or drinking-water supply. The second host ingests these organisms and becomes infected. Prior to development of modern sanitation systems, this transmission route was unimpeded, leading to numerous outbreaks of disease (Viessman and Hammer, 1985). Today, even in developed areas, animal manure, municipal sludge, septic systems, and sanitary sewers discharge to water bodies (ground water or surface water); therefore, water still is a potential route for transmission of these organisms. In developing modern watertreatment systems, various processes have been enacted to ensure the water intended for human consumption is not contaminated by such organisms. The USEPA sets a maximum contaminant level (MCL) for drinking water for constituents known to cause diseases in humans. The MCL for enteric viruses is listed as 'treatment technique,' which means a process intended to reduce the level of a contaminant is required. Stated another way, there is no regulated acceptable level of enteric virus in drinking water. The maximum contaminant level goal (MCLG) is zero viruses. An MCLG is the level of a contaminant in drinking water below which there is no known or expected risk to health. MCLG's allow for a margin of safety and are non-enforceable public health goals. The detection of viruses, however, is a very expensive and time-consuming process, so instead of testing all drinking-water systems for viruses, an alternative system has been developed. One part of the system is treatment of water supplies, and the other is detection of organisms that indicate fecal contamination.

Treatment systems for surface-water supplies including flocculation (settling out of large particles), filtration (removal of smaller particles), and disinfection (processes such as chlorination-to inactivate microorganisms) are required for surface-water supplies since the enactment of the Safe Drinking Water Act in 1974 (U.S. Environmental Protection Agency, 2000a). Surface-water supplies are vulnerable to many types of microbial contaminants, and, therefore, all are required to perform disinfection. Ground-water supplies, however, are not necessarily required to use disinfection. The determination as to whether or not disinfection is necessary is based on sampling for indicators of fecal contamination. Total coliform and E. coli are the most commonly used indicators of fecal con- tamination. A certain amount of filtration takes place in the ground-water system. Some water supplies are free from microorganisms; therefore, the expense of disinfection may be an unnecessary cost to the water supplier.

Use of fecal bacteria as indicators of potentially contaminated water sources has developed along various lines. The first is that the presence of E. coli, which only originates in the intestines of warmblooded animals, is evidence of direct fecal contamination of a water supply. Presence of E. coli does not guarantee other water-borne pathogens are in this water; however, it raises the strong possibility that they could be. Additionally, E. coli can be pathogenic. Although many strains of E. coli are harmless, some strains of E. coli such as O157:H7 can cause disease. Total coliforms are not necessarily an indicator of fecal contamination but are used as an indicator that contamination from the land surface has entered the well. Detection of total coliform and E. coli in ground-water supplies triggers enforcement steps including additional monitoring and, if the source cannot be identified and removed, disinfection. E. coli is one species of total coliforms.

The use of total coliform bacteria as indicator organisms is based on the ratio of total coliform bacteria to other pathogens. This ratio is very high, because coliform bacteria are shed by the entire population and pathogens are shed only by individuals infected with enteric diseases. If the die-off rate of pathogens exceeds the die-off rate for coliform, the absence of coliform bacteria in water should be a good indication that the water also is free from pathogens (Viessman and Hammer, 1985). This theory has been effective for protection against bacterial disease; however, enteric pathogens can be either bacterial, viral, or protozoan. Viruses are much smaller than bacteria. The viruses range in size from 0.023 to $0.080 \mu \mathrm{m}$ (microns) and have different transport properties than bacteria that ranges in size from 0.5 to $3 \mu \mathrm{m}$ (Abbaszadegan and others, 1998). Protozoans range from 4 to $15 \mu \mathrm{m}$ and do not travel as well in ground water in most aquifer systems but could be a concern because of their resistance to disinfection (Abbaszadegan and others, 1998). Therefore, the level of protection afforded against all pathogens on the basis of fecal indicator bacteria is uncertain (Francy and others, 2000). 


\section{Purpose and Scope}

This report describes the occurrence and distribution of pathogens and indicator organisms in ground water used for noncommunity water supply and compares the occurrence of pathogens in ground water between carbonate and crystalline aquifers in Pennsylvania. Also, microbiological indicators were evaluated as surrogates for those pathogens. The results were based on samples collected from 59 noncommunity water supplies from September 2000 to January 2001 in four aquifers across the Commonwealth of Pennsylvania. Ground-water samples were analyzed for human enteric viruses, including reoviruses and enteroviruses. Helicobacter pylori (H. pylori) also was analyzed as a pathogen. Indicator organisms analyzed included total coliform, E. coli, enterococcus, Clostridium perfringens (C. perfringens), somatic coliphage, and male-specific coliphage. The data are analyzed with respect to factors affecting the occurrence of microbiological contaminants such as land use, geology, and well construction. The results of this study can help water suppliers in
Pennsylvania make informed decisions about the need for treatment for viral and/or bacterial contaminants in ground water. This information also could be useful for the USEPA and the PaDEP in developing the Ground Water Rule.

\section{Description of Study Area}

The Commonwealth of Pennsylvania covers $44,820 \mathrm{mi}^{2}$ and is composed of seven physiographic provinces: Atlantic Coastal Plain, Piedmont, New England, Blue Ridge, Ridge and Valley, Appalachian Plateaus, and Central Lowlands (Berg and others, 1980). These physiographic provinces are further subdivided into 18 physiographic sections. For this report, aquifers in the State are grouped into three general aquifer types on the basis of the bedrock that composes the aquifer. These three groupings are limestone and dolomite (carbonate aquifers); sandstone, siltstone, and shale (siliciclastic aquifers); and igneous and metamorphic rocks (crystalline aquifers) (Berg and others, 1980) (fig. 1). In some areas of the State, unconsolidated materials such as sand and gravel

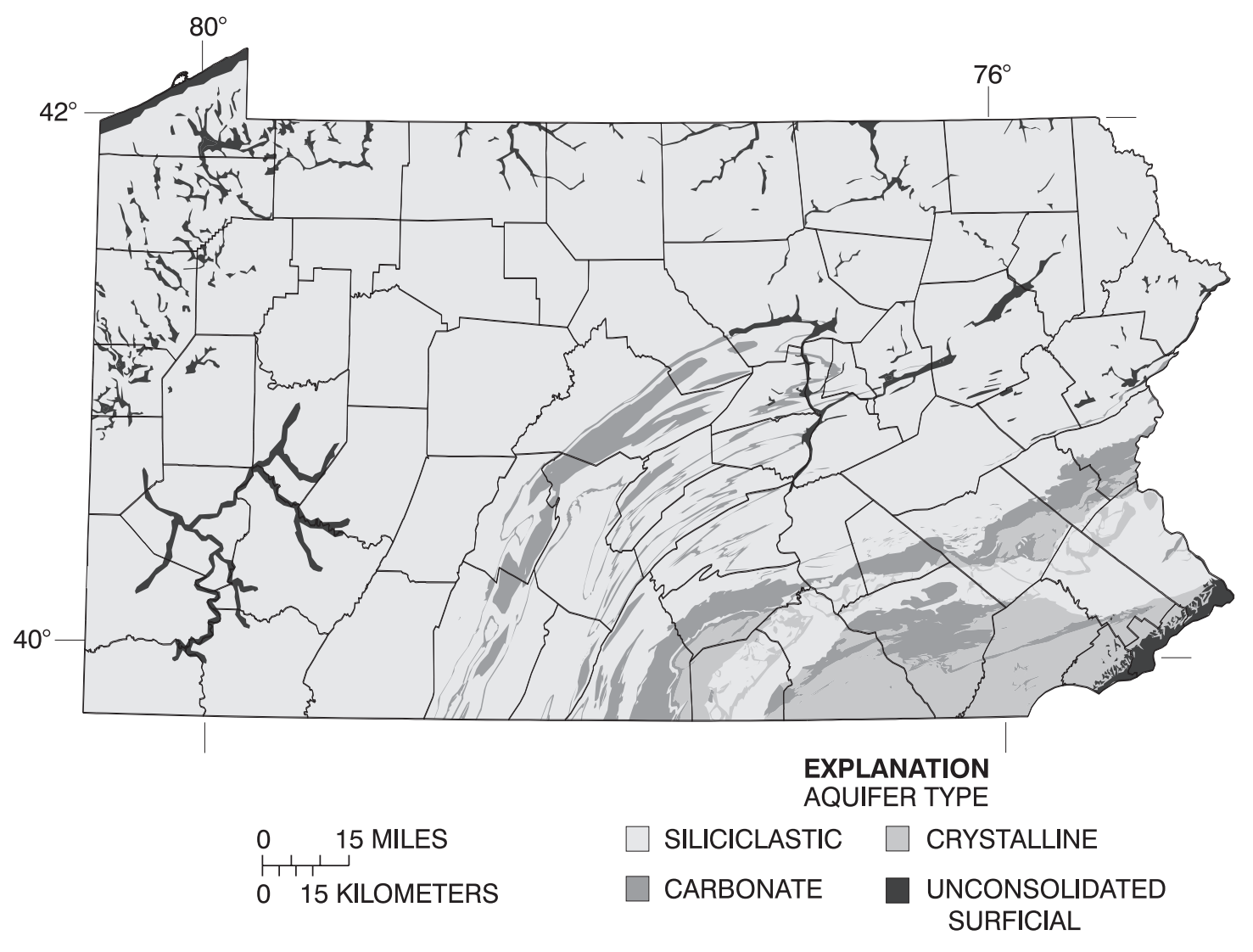

Figure 1. Aquifers types in Pennsylvania (Berg and others, 1980; Soller and Packard, 1998). 
overlie the bedrock and are of sufficient depth to be considered an aquifer. These areas form the fourth general aquifer type discussed herein (unconsolidated surficial aquifers) (Soller and Packard, 1998).

\section{Land Cover}

Land cover in the State is diverse and important in determining potential microbiological contamination. Land cover determines potential sources of fecal contamination of ground water. Forested areas have wildlife as a potential source of fecal contamination. Agricultural and rural areas have animal wastes, municipal sludge used as fertilizer, and septic systems as potential sources of fecal contamination. Urban areas have septic systems as potential sources of contamination, or if the area is served by public sewers, leaking sewer lines could be a source of fecal contamination. Land-cover data from the early 1990's (Vogelmann and others, 1998a; Vogelmann and others, 1998b) show that forests and wetlands cover 65 percent of the land area of Pennsylvania (fig. 2). Agricultural land covers about 28 percent of the State. Urban land covers about 4 percent of the land area including low-intensity developed areas, high-intensity commercial areas, and high-intensity residential areas. The remaining 3 percent is covered by quarries and mines, water, parks, golf courses, and barren land. The distribution of these land-cover types varies across the State as topography, physiography, and agricultural practices vary. In some areas, a single land cover is dominant; however, many areas contain a mixture of agricultural, forested, and other land covers.

\section{Geology and Aquifer Characteristics}

One of the primary areas studied was the carbonate-bedrock aquifers. Carbonate aquifers are highly susceptible to contamination because large fractures facilitate the rapid movement of water through the ground-water system (Fishel and Lietman, 1986). Limestone and dolomite bedrock commonly have large fractures caused by weathering, and in many areas of the State, karst features such as sinkholes and caverns have an appreciable effect on ground-water flow. The infiltration capacity of soils overlying the carbonate bedrock is classified as excellent (Susquehanna River Basin Coordinating Committee, 1970), and the topography commonly is flat. In carbonate areas, much of the precipitation infiltrates through the soil into large fractures or sinkholes in the bedrock instead of running off into streams. This infiltrated water commonly carries contaminants directly into the ground water. Studies have shown water from wells in areas underlain by carbonate bedrock is more likely to contain bacteria (Bickford and others, 1996) and is more likely to contain other contaminants such as nitrate (Lindsey and others, 1997) than water from wells in other bedrock types.

The second area studied was the crystallinebedrock aquifers, which in some cases are as susceptible to contamination as areas underlain by carbonate bedrock (Lindsey and others, 1997). Crystalline rock includes igneous and metamorphic rocks such as schist, gneiss, gabbro, phyllite, metavolcanic rocks, and quartzite (Risser and Siwiec, 1996). Ground water in areas underlain by crystalline bedrock is present primarily in the bedrock fractures and pores in the saturated part of the regolith above the crystalline bedrock (Risser and Siwiec, 1996). The infiltration capacity of the soil overlying crystalline bedrock is classified as good (Susquehanna River Basin Coordinating Committee, 1970). Previous studies have shown groundwater contamination by bacteria (Bickford and others, 1996) and other contaminants (Lindsey and others, 1997) in areas underlain by crystalline bedrock.

Samples also were collected for this study as a reconnaissance effort in the surficial aquifers of the State that consist of unconsolidated materials. The susceptibility of unconsolidated deposits that form a mantle over the bedrock throughout the State is not well understood. In areas where these unconsolidated deposits are thick enough and produce enough water, they become important aquifers (fig. 1). These areas also are referred to as unconfined surficial aquifers because it is the surface material storing the water, and the aquifers are not protected from surface infiltration by confining layers. Unconsolidated surficial aquifers are found in the Atlantic Coastal Plain Province (extreme southeast area of the State), the Eastern Lake Province (extreme northeast area of the State), in river terrace deposits near the Allegheny-Monongahela River (southwestern part of the State), and in glaciated areas (northern part of the State) (fig. 1). Unconsolidated surficial aquifers composed of coarse-grained sediments, such as sand or gravel, generally are productive aquifers (Lindsey and Bickford, 1999). In the northern glaciated valleys, glacial deposits, such as stratified drift or glacial outwash composed of sand and gravel, were con- 


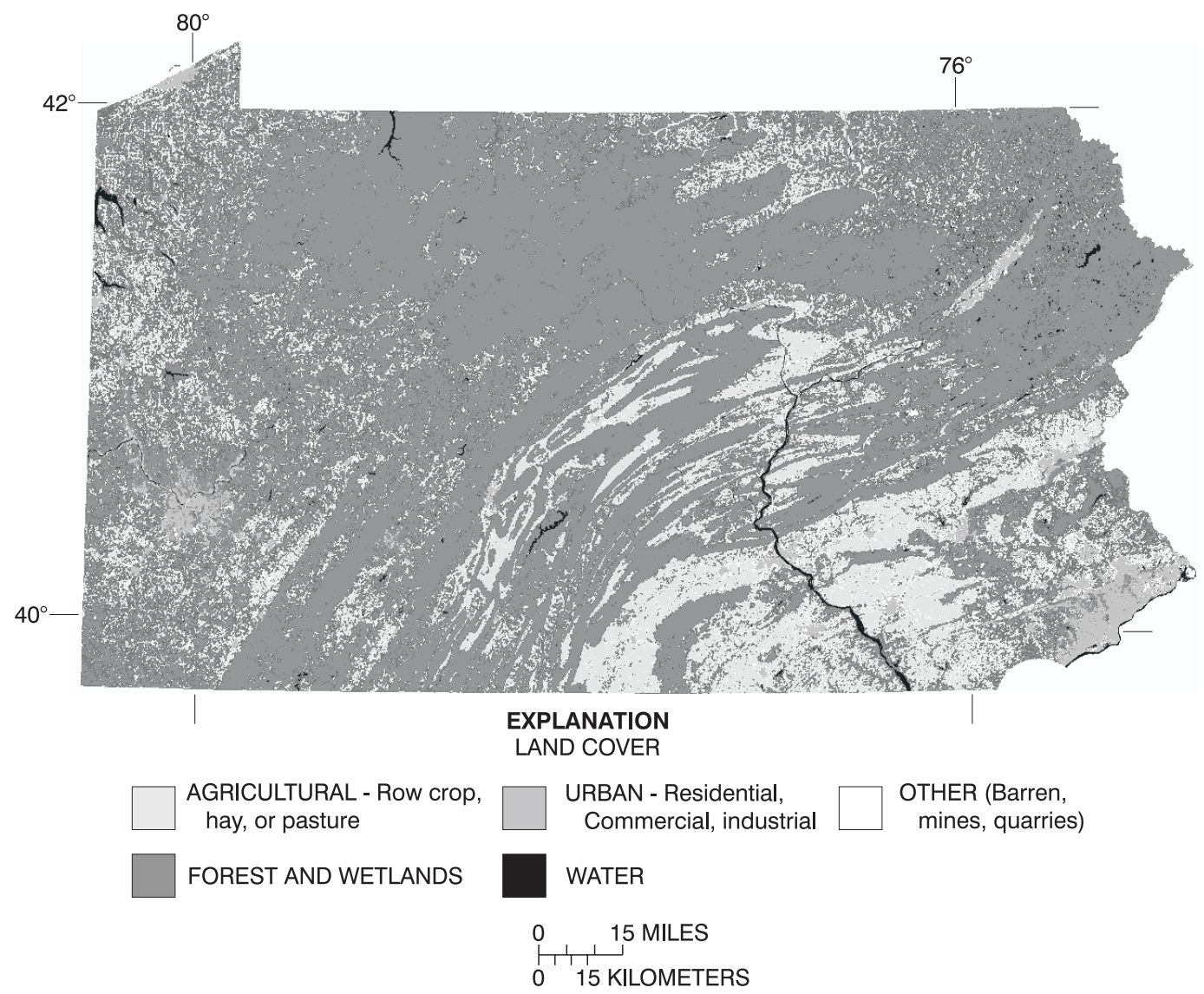

Figure 2. Land covers in Pennsylvania (Vogelmann and others, 1998a; Vogelmann and others, 1998b).

sidered as a separate aquifer from the bedrock aquifer below. In the glaciated areas where the glacial deposits are composed of till, a material with a high clay content, the till was not included in the study of the unconsolidated surficial aquifers. Aquifers with coarse-grained materials, such as sand and gravel, theoretically would be vulnerable to the leaching of bacteria and viruses.

Few studies have been done to determine whether or not bacterial contamination was present in any of the unconsolidated surficial aquifers in Pennsylvania. Bacterial contamination has been found in unconsolidated surficial aquifers in Erie County, Pa. (Buckwalter and others, 1996). However, this study was limited in that only six samples were collected for bacterial analysis. Other studies have been done in states neighboring Pennsylvania with similar unconsolidated surficial aquifers (sand and gravel). A study in Endicott, N.Y. (Randall, 1970), found high levels of coliform bacteria in a municipal well in a sand and gravel aquifer in close proximity to the Susquehanna River. The source of pollution was discharge from municipal sewage into the Susquehanna River from a wastewater-treatment plant that caused high concentrations of coliform during low-flow conditions. A study in Ohio (Shindel and others, 1999) analyzed bacterial concentrations in ground water from eight wells constructed in glacial deposits. The results indicated that four of the eight wells were positive (at least one bacteria colony present) for total coliform and none of the eight wells contained water with $E$. coli. A study in Minnesota by Walsh and Major (2000) was done to establish baseline data on the occurrence of viral pathogens and indicator organisms in 76 public water-supply wells. The study particularly was relevant to the current virus study in Pennsylvania because of the similarity in the constituents analyzed. Of the Minnesota wells, 30 were in the unconsolidated surficial aquifer. Six of the 30 wells tested positive for total coliform and 1 tested positive for E. coli. One sample from a well in the 
unconsolidated surficial aquifer tested positive for male-specific coliphage and none of the samples analyzed from wells in the unconsolidated surficial aquifer had enteric viruses present.

Samples also were collected for this study as a reconnaissance effort in the siliciclastic aquifers. The siliciclastic aquifers in Pennsylvania commonly have smaller fractures and more tortuous flowpaths than other bedrock aquifers and generally have a lower potential for leaching of contaminants into ground water than aquifers underlain by the other bedrock types (Lindsey and others, 1997). The study by Bickford and others (1996) showed that these aquifers had the lowest frequency of bacteria detection; however, it was included in the current study because it covers a large geographic area of the State and many wells are in siliciclastic aquifers. Soils weathered from sandstone generally have good infiltration capacity, whereas soils weathered from shale have poor infiltration capacity (Susquehanna River Basin Coordinating Committee, 1970).

\section{Noncommunity Supply Wells and the Ground Water Rule}

In the Commonwealth of Pennsylvania, there are three basic classes of public water supplies. A public water supply that provides water to a town, city, or other municipality is a community water supply. A community water system is defined as "a public water system which serves at least 15 service connections used by year-round residents or regularly serves at least 25 year-round residents" (U.S. Environmental Protection Agency, 2000a). These water suppliers generally are required to disinfect ground water, regardless of detections of indicator organisms. The remaining public supply systems are noncommunity water supplies that are defined as "a public water system that is not a community water system" (U.S. Environmental Protection Agency, 2000a).

Noncommunity water supplies fall into two categories on the basis of the population served. One group is called a nontransient noncommunity supply because the population consuming this water does not change over time. The definition of a nontransient noncommunity supply is "a public water system that is not a community water system and that regularly serves at least 25 of the same persons over 6 months per year" (U.S. Environmental Protection Agency, 2000a). Examples of this water-supply type would be a factory or a school.
The second group is called transient noncommunity supply because most individuals will use this water supply infrequently. The definition of a transient noncommunity supply is "a noncommunity water system that does not regularly serve at least 25 of the same persons over 6 months per year" (U.S. Environmental Protection Agency, 2000a). Examples of this supply type would be restaurants, campgrounds, gas stations, and similar locations that have their own well as a source of drinking water. Approximately 7,820 transient noncommunity supply wells are present in Pennsylvania (fig. 3). Currently, the decision on whether or not noncommunity supply wells use disinfection is based on the outcome of testing for total coliform and E. coli, which are monitored on a quarterly basis at a minimum (U.S. Environmental Protection Agency, 2000a). It is important to note that, unlike chemical contaminants that commonly affect human health after long-term exposure (years), a single exposure to a microbiological pathogen can cause a serious disease or, in extreme cases, death. Because of the transient nature of the population served, the requirements for testing and treatment of water for the transient noncommunity supplies are the least stringent.

Although a system is in place to test noncommunity water supplies for contaminants, some potential weaknesses exist in the system. Noncommunity water supplies commonly are at businesses, and operating that business is the primary focus of the operator or owner. Consequently, noncommunity water suppliers generally direct less attention to the siting of wells and training of personnel responsible for water treatment than community water suppliers. It is not surprising that 77 percent of the waterborne disease outbreaks in noncommunity water supplies were attributed to source water contamination (as opposed to contamination from the distribution systems), whereas only 26 percent of outbreaks in community supply wells were attributed to source water contamination (Macler, 1996). Noncommunity water-supply systems in Pennsylvania commonly are in rural areas where malfunctioning septic systems may adversely affect ground-water quality at the wellhead. For the most part, areas served by public water also have public sewer, and areas that rely on wells as a water source commonly use on-lot septic systems. Currently, little information is available on the occurrence of viruses in ground water; therefore, it is difficult to establish treatment guidelines for water suppliers. 


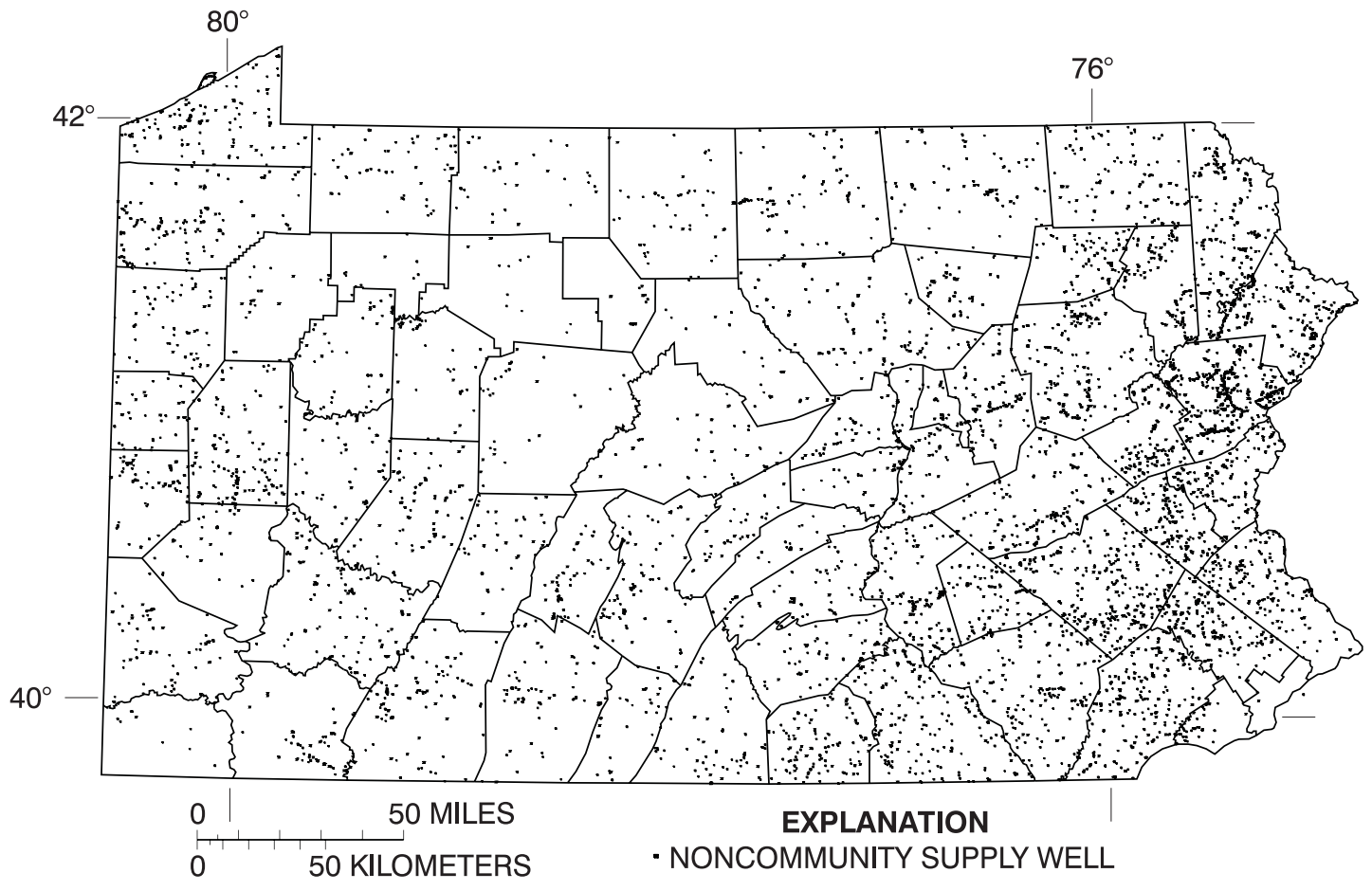

Figure 3. Locations of transient noncommunity supply wells in Pennsylvania.

The USEPA currently (2001) is dealing with the following situation: decisions on whether or not to implement disinfection are based on fecal indicator bacteria; however, those indicator organisms do not necessarily provide assurance that pathogens are not present. The USEPA has proposed the Ground Water Rule to deal with this situation (U.S. Environmental Protection Agency, 2000b). "The Ground Water Rule establishes multiple barriers to protect against bacteria and viruses in drinking water from ground-water sources and will establish a targeted strategy to identify ground-water systems at high risk for fecal contamination (U.S. Environmental Protection Agency, 2000b)." The Ground Water Rule was proposed in May 2000 and is intended to be implemented in 2001. The States will implement the Ground Water Rule. The Commonwealth of Pennsylvania, in preparing for this implementation, has funded this study on the occurrence of viruses and bacteria. Information gathered from this project will be used to begin to quantify whether or not some areas of the State are at a higher risk for contamination by pathogens and fecal indicator organisms than other areas.

\section{Acknowledgments}

The authors thank John Diehl and Joseph Lee of the PaDEP, who provided a great deal of assistance in developing the project and providing input to USGS personnel as the project was being implemented. The authors also would like to acknowledge the assistance of Katherine Baker of the Pennsylvania State University, Environmental Microbiology Research Laboratory, Harrisburg Campus, for her work in analyzing H. pylori; and Susan Boutros and John Chandler and the rest of the staff of Environmental Associates Laboratory for their work in analyzing the viruses by cell culture as well as most of the indicator organisms. All the researchers involved in the laboratory analyses provided a great deal of assistance to the authors in interpreting the results. The authors also would like to thank Dale Long and Richard Rogers of the USEPA for their support in developing the project and providing resources for the H. pylori sampling. The authors also would like to thank the reviewers for their helpful additions to the report. 


\section{SAMPLING DESIGN}

The sampling design was based on a combination of factors such as water use, population density, and results of previous studies (table 1). These factors led to the selection of the carbonate and crystalline aquifers as the primary focus of the study. The areas of the State these aquifers underlie are most vulnerable to microbiological contaminants, on the basis of the available data (Bickford and others, 1996), and also have a high density of noncommunity supply wells (table 1). However, because of lack of data on viruses, it was considered important to include wells in the remaining areas of the State. On the basis of these factors, a representative subset of the available noncommunity supply wells was selected in the following settings: 25 in areas underlain by carbonate bedrock, 25 in areas underlain by crystalline (igneous and metamorphic) bedrock, 5 in areas underlain by siliciclastic bedrock, and 5 in areas underlain by unconsolidated surficial aquifers. The distribution was determined so that the two primary aquifer types had sufficient numbers of samples for statistical comparisons of results. A computerized random selection program (Scott, 1990) was used to delineate the potential sampling areas. This program subdivides a selected study area into equal subareas on the basis of the desired number of samples, and a well is selected for sampling in each subarea. The sites in the other two geologic settings were sampled for reconnaissance purposes. Selecting random wells from the targeted population and developing a quality-assurance plan and sampling protocols were done primarily by USGS personnel with assistance from PaDEP.
The organisms in the samples collected were classified as either pathogens (viruses, $H$. pylori) or indicators of fecal contamination (total coliform, E. coli, enterococcus, coliphage, and C. perfringens). Viruses were the initial focus of the study; $H$. pylori was included in an attempt to provide additional information on the occurrence of organisms on the USEPA Contaminant Candidate List. H. pylori is a bacterium of fecal origin and has been found to cause intestinal problems such as gastric ulcers and also is related to stomach cancer (Horsburgh and Nelson, 1997). E. coli was classified as an indicator organism because it provides evidence of direct fecal contamination. Although some strains of $E$. coli are pathogenic, this project did not analyze which strains were present, so it was not included as a pathogen. The media used for this study to detect coliform bacteria does not detect the O157:H7 strain of E. coli, the most significant virulent strain. Total coliforms were included as indicator organisms because of their current regulatory use. Enterococci are a subgroup of the fecal streptococci group. Enterococci are considered to be better indicators of fecal contamination than are fecal streptococci and also are useful in assessing transport of fecal contamination in ground water (Francy and others, 2000). C. perfringens also is a bacterium of primarily fecal origin. It was included as an indicator organism because of its resistance to disinfection and environmental stresses (Francy and others, 2000). Coliphage also was included as an indicator organism. Coliphage are viruses that infect coliform bacteria. Both somatic coliphage and male-specific coliphage were analyzed. Somatic coliphages are found in both fecal-contaminated and uncontaminated waters and may not be

Table 1. Number and density of noncommunity supply wells in Pennsylvania by aquifer type

\begin{tabular}{|c|c|c|c|c|}
\hline Aquifer type & $\begin{array}{c}\text { Area } \\
\text { (square } \\
\text { miles) }\end{array}$ & $\begin{array}{l}\text { Number of } \\
\text { noncommunity } \\
\text { supply wells }\end{array}$ & $\begin{array}{c}\text { Density of } \\
\text { noncommunity } \\
\text { supply wells } \\
\text { (well per square mile) }\end{array}$ & $\begin{array}{c}\text { Results of previous } \\
\text { microbiological studies of } \\
\text { aquifers }{ }^{1}\end{array}$ \\
\hline Carbonate aquifers & 2,930 & 616 & 0.21 & $\begin{array}{l}\text { Highest bacteria counts and } \\
\text { percentage of detections }\end{array}$ \\
\hline Crystalline aquifers (Piedmont only) & 1,760 & 527 & .29 & $\begin{array}{l}\text { Medium number of bacteria } \\
\text { counts and percentage of } \\
\text { detections }\end{array}$ \\
\hline Siliciclastic aquifers & 37,810 & 5,923 & .16 & $\begin{array}{c}\text { Lowest bacteria counts and } \\
\text { percentage of detections }\end{array}$ \\
\hline Unconsolidated aquifers & 1,800 & 627 & .35 & No data available \\
\hline Other $^{2}$ & 520 & 127 & .24 & No data available \\
\hline
\end{tabular}

${ }^{1}$ From Bickford and others (1996).

${ }^{2}$ Crystalline aquifers in Blue Ridge Physiographic Section and Reading Prong Physiographic Section not included in study. 
reliable indicators of fecal contamination. Malespecific coliphages found in environmental samples presumably come from warm-blooded animals. Because their size is relatively similar to other viruses, coliphages are thought to represent potential for transport of viruses (Francy and others, 2000).

Samples were collected from different types of noncommunity water suppliers. Sites sampled included restaurants, swim clubs, golf courses, oil companies, campgrounds, grocery stores, churches, schools, and many other businesses and organizations that provide drinking water to the public. The vast majority of the samples were transient noncommunity supply wells; two wells were nontransient noncommunity supply wells. Sites also were selected on the basis of surrounding land use. Sites near a potential source of contamination such as septic tanks or agricultural areas were selected, although some sites were in areas served by public sanitary sewers. Predominantly forested sites with no visible contamination source were avoided; however, campgrounds in forested areas with onsite septic systems or pit latrines were included. Because participation in the sampling program was voluntary, the population of wells selected potentially was biased. In many cases, water suppliers with known water-quality problems declined to participate, and others were willing to participate because they were confident that they did not have water-quality problems.

\section{METHODS OF STUDY}

Field data collection, laboratory analyses, and statistical analyses were done in a manner consistent with approved and (or) published methods. Methods for field data collection were available from published reports and were followed in the field. Additional data on well construction and potential contamination sources were collected as available.

\section{Field Data Collection}

Samples were collected by USGS personnel for the set of wells selected, using the Information Collection Rule (ICR) (U. S. Environmental Protection Agency, 1996) sampling method. Field data were collected and documented on a project-specific field form to provide ancillary information about each well. Information on well construction and local wellhead-protection plans was collected from the water supplier. In some areas, only one well was available for sampling and well-construction information was not available; therefore, the amount of available well-construction data varies. Water levels were measured except for wells where the well cap could not be removed without the assistance of a plumber. In addition, field waterquality data were collected for each well. These data included $\mathrm{pH}$, dissolved oxygen, specific conductance, and temperature. Samples for indicators of potential viral contamination such as total coliform bacteria, E. coli, enterococcus, C. perfringens, somatic coliphage, and male-specific coliphage also were collected. Other ancillary data collected on the field form included the location of nearest septic system, indications of animal manure or municipal sludge application, or other potential sources of pathogens and indicators observed.

At each site, the sample was collected at an untreated water source, as close to the well as possible. Plumbing was inspected to insure the sample was not receiving any treatment at the source of the sample collection. Sterile gloves were worn when handling samples. The sampling apparatus, consisting of a pressure gauge, flowmeter, and discharge hose, was connected to the raw water source and 20 gal of water was allowed to pass through the apparatus to rinse away any residual chlorine from the cleaning process. Following this initial purge, the virus filter and housing was connected between the pressure gauge and flowmeter, and the virus sample was collected. A minimum of 80 gal (300 L (liters)) of water was allowed to pass through the filter at a rate of less than 3 gal per minute and with pressure not exceeding $30 \mathrm{psi}$ (pounds per square inch). The ICR method for filtering 80 gal of water is based on sampling of surface water. Because ground water is likely to have lower concentrations of viruses than surface water, it is desirable to filter more than the ICR minimum requirement of 80 gal when collecting groundwater samples for viral analysis. If conditions were favorable, a maximum sample volume of 264 gal (1,000 L) was collected. Specific conductance, $\mathrm{pH}$, dissolved oxygen, and temperature were measured from a flow chamber connected to the discharge hose. With the filter left inside the filter housing, excess water was drained from the filter housing, and the virus filter was packed with ice packs and shipped overnight to Environmental Associates Laboratory, Ithaca, N.Y. Samples for male-specific and somatic coliphage were taken from the virus filter. 
Following the collection of the virus sample, samples also were collected for enterococci and C. perfringens. These samples were collected by filling a 1-L sterile bottle, which was chilled immediately and sent with the virus filter to Environmental Associates Laboratory. H. pylori samples were collected in a $250 \mathrm{~mL}$ (milliliter) sterile whirlpack, chilled immediately, and delivered within 48 hours to the Pennsylvania State University Environmental Microbiology Research Laboratory, Middletown, Pa. E. coli and total coliform samples were collected in a $125-\mathrm{mL}$ sterile bottle, immediately chilled, and delivered within 24 hours to the PaDEP laboratory in Harrisburg, Pa. Qualityassurance samples for $E$. coli and total coliform were collected in sterile 1-L bottles and processed immediately on site by USGS personnel.

If the turbidity of samples exceeded 75 nephelometric turbidity units (NTU) or other conditions were present that would prevent the minimum sample volume (80 gal) to pass through the filter, a prefilter was used to insure that the virus filter did not become clogged. The prefilter was connected directly prior to the virus filter and sampling was conducted in the same manner as without the prefilter. Both filters were shipped to the laboratory for analysis following sample collection.

Disinfection of filter housing and collection bottles was done by the analyzing laboratories according to the ICR method. Sterilization of pressure gauges, flowmeters, and the fluid proportioning injector module was done by USGS personnel in the Pennsylvania District laboratory in accordance with the ICR method (U.S. Environmental Protection Agency, 1996). The cleaning procedure was done by recirculating 0.1 percent chlorine solution through all of the items for 30 minutes, insuring that the solution came in full contact with all surfaces. Following disinfection, equipment was dechlorinated by recirculating a solution containing $2.5 \mathrm{~mL}$ of 2 percent sterile sodium thiosulfate per liter of sterile water.

\section{Microbiological Analysis}

Laboratory analysis for viruses and indicator organisms was done by Environmental Associates Laboratory, a contract laboratory approved by the USEPA for the ICR method (table 2). The ICR total culturable virus assay primarily detects human

Table 2. Microbiological organisms analyzed in the study

[PaDEP, Pennsylvania Department of Environmental Protection; L, liter; mL, milliliter; PFU, plaque forming units; MPN, most probable number; CFU, colony forming units; USEPA, U.S. Environmental Protection Agency]

\begin{tabular}{|c|c|c|c|c|c|}
\hline Organism & Method & $\begin{array}{l}\text { Analytical } \\
\text { laboratory }\end{array}$ & Volume analyzed & Reporting units & Reference \\
\hline Enteric virus & Cell culture & $\begin{array}{c}\text { Environmental } \\
\text { Associates }^{1}\end{array}$ & 200 to $1,000 \mathrm{~L}$ & PFU per $100 \mathrm{~L}$ & USEPA, 1996 \\
\hline Helicobacter pylori & $\begin{array}{l}\text { Immunofluorescent } \\
\text { antibody }\end{array}$ & $\begin{array}{l}\text { Pennsylvania } \\
\text { State } \\
\text { University }^{2}\end{array}$ & $500 \mathrm{~mL}$ & $\begin{array}{l}\text { Organisms per } \\
\mathrm{mL}\end{array}$ & $\begin{array}{l}\text { Hegarty and others, } \\
1999\end{array}$ \\
\hline Escherichia coli & Colilert & $\mathrm{PaDEP}^{3}$ & $100 \mathrm{~mL}$ & MPN per $100 \mathrm{~mL}$ & $\begin{array}{l}\text { Clesceri and others, } \\
1998\end{array}$ \\
\hline Total coliform & Colilert & PaDEP & $100 \mathrm{~mL}$ & MPN per $100 \mathrm{~mL}$ & $\begin{array}{l}\text { Clesceri and others, } \\
1998\end{array}$ \\
\hline $\begin{array}{l}\text { Clostridium } \\
\text { perfringens }\end{array}$ & Membrane filter & $\begin{array}{c}\text { Environmental } \\
\text { Associates }\end{array}$ & $100 \mathrm{~mL}$ & CFU per 100 mL & USEPA, 1996 \\
\hline $\begin{array}{l}\text { Male-specific } \\
\text { coliphage }\end{array}$ & Plaque assay & $\begin{array}{c}\text { Environmental } \\
\text { Associates }\end{array}$ & 200 to $1,000 \mathrm{~L}$ & PFU per $100 \mathrm{~L}$ & USEPA, 1996 \\
\hline $\begin{array}{l}\text { Somatic } \\
\text { coliphage }\end{array}$ & Plaque assay & $\begin{array}{c}\text { Environmental } \\
\text { Associates }\end{array}$ & 200 to $1,000 \mathrm{~L}$ & PFU per $100 \mathrm{~L}$ & USEPA, 1996 \\
\hline Enterococcus & Enterolert & $\begin{array}{c}\text { Environmental } \\
\text { Associates }\end{array}$ & $100 \mathrm{~mL}$ & CFU per 100 mL & $\begin{array}{l}\text { American Society for } \\
\text { Testing and } \\
\text { Materials, } 2000\end{array}$ \\
\hline
\end{tabular}


enteric viruses, including reoviruses and enteroviruses. The ICR total culturable virus assay is a cell culture method that uses African Green Monkey kidney cells as a host for the viruses to grow. The results are enumerated as a number of plaqueforming units per $100 \mathrm{~L}$. The other organisms analyzed by the Environmental Associates Laboratory included C. perfringens, male-specific and somatic coliphage, and enterococcus. The ICR analysis method (U.S. Environmental Protection Agency, 1996) was used for C. perfringens and both types of coliphage. Enterococcus was analyzed using the IDEX Enterolert method (American Society for Testing and Materials, 2000).

Samples collected for H. pylori were analyzed by the Pennsylvania State University Environmental Microbiology Research Laboratory. The method used was a combined tetrazolium salts reduction, fluorescent antibody technique (Hegarty and others, 1999). The samples collected for total coliform and E. coli were analyzed by the PaDEP Laboratory. The method used for this analysis was the IDEX Colilert method (Clesceri and others, 1998). Samples analyzed for total coliform and E. coli by the USGS for quality-assurance purposes were analyzed using USEPA method 1105 (U.S. Environmental Protection Agency, 1991). This method required membrane filtration of a $100-\mathrm{mL}$ sample, followed by incubation on M-Endo media at $35^{\circ} \mathrm{C}$ $\left(+/-0.5^{\circ}\right)$ for 24 hours (+/- 2 hours). Following incubation, those colonies exhibiting a green sheen were counted as total coliform colonies. Total coliform positive filters were transferred to NA-MUG agar for an additional 4-hour incubation. E. coli colonies were identified as those colonies exhibiting a fluorescent halo when observed under a long-wave ultraviolet lamp.

\section{Statistical Analysis}

Statistical tests were performed on the data in order to determine factors affecting the occurrence of viruses and numerical relations between pathogens and indicator organisms. The statistical tests were chosen on the basis of the number of samples available, the distribution of the data, and the amount of censoring. For all statistical tests, an alpha value of 0.05 was used; a test with an alpha value of less than 0.05 indicates that there is greater than a 95-percent probability the results of that test are not due to random chance. For comparing the occurrence of the pathogens and indicators among aquifer types, only the two aquifers (carbonate and crystalline) with sufficient numbers of samples were compared. Because of the degree of censoring in this data set (over half of the data were nondetects), contingency tables using detect as compared to nondetect and carbonate as compared to crystalline are the appropriate tests (Helsel and Hirsch, 1992). The contingency table used in this manner could determine whether or not one category had a significantly different probability of having the pathogen or indicator detected than the other category.

For testing the relations of the land cover in a 1,500 -ft radius surrounding each well to the occurrence of pathogens and indicators, the data were grouped. One group consisted of those wells with organisms detected, and the other group was made up of those wells with no organisms detected.

A logistic regression (SAS Institute, 1990) was used to test whether the percentage of a given land cover was significantly different in wells with organisms detected than wells with no organisms detected. All data were used for this test. This test also was used to determine if well depth was significantly different in wells with organisms detected than wells with no organisms detected.

For comparing two numeric variables such as virus concentration and total coliform concentration, the degree of censoring also affected the tests used. Again, the contingency table was the only valid test available (Helsel and Hirsch, 1992). In this case, the four values in the contingency table matrix are shown in table 3 . This test showed whether or not co-occurrence of the indicator and pathogen were statistically significant or random.

Table 3. Sample contingency table matrix for comparison of pathogens and indicator organisms

\begin{tabular}{cc}
\hline $\begin{array}{c}\text { Number of sites with indicator organism detected, } \\
\text { Pathogen not detected }\end{array}$ & $\begin{array}{c}\text { Number of sites with both Pathogen and indicator } \\
\text { organism detected }\end{array}$ \\
$\begin{array}{c}\text { Number of sites with neither Pathogen nor indicator } \\
\text { organism detected }\end{array}$ & $\begin{array}{c}\text { Number of sites with indicator organism not } \\
\text { detected, Pathogen detected }\end{array}$ \\
\hline
\end{tabular}




\section{Quality-Control Results}

Quality-control samples were collected to ensure the data were of known and good quality. The quality-control sample types were blanks and replicates. Spikes or blind samples of a known concentration were not conducted. The purpose of the blanks was to ensure that field and lab techniques (handling of equipment or disinfecting between sites) were not a contamination source. Two blank samples were collected using the field techniques described in the methods section, with the exception that the water source was sterile buffered water. Approximately $2 \mathrm{~L}$ of sterile water was pumped through the filter apparatus using the same pump that was used in the cleaning process. The filters were handled in the same manner as the field samples and sent to the analyzing laboratory with a normal field identification. Both samples were negative for culturable viruses. One of these blank samples was collected near the beginning of the sampling period, to establish that equipment sterilization was adequate; the other sample was collected later in the sampling, to ensure those procedures were still effective. With each blank, a 1-L blank sample also was submitted for C. perfringens, coliphage, and enterococcus. Blanks for C. perfringens, coliphage, and enterococcus were nondetects.

The other quality-control samples were replicate samples collected for $E$. coli and total coliforms by the USGS using the membrane filtration (MF) method (table 4). Replicates were not conducted for the other pathogens and indicators because of the low probability of detection and the associated cost of analysis. This quality-control step compared two methods of sample analysis to determine if the MF method using M-Endo and NA-MUG mediums (samples processed by USGS personnel immediately on site) was more likely to detect bacteria than samples analyzed by the most probable number (MPN) method using Colilert media (samples processed within 24 hours by PaDEP personnel at the PaDEP laboratory). The results of this testing showed similar results; however, the sites randomly selected for replicate analysis turned out to represent only the high and low ends of the concentration range (table 2). Of the eight quality-assurance samples, seven showed no detections of $E$. coli or total coliform for either method. One sample was too numerous to count for total coliform and no detection of E. coli (MF method) and 200 colonies per $100 \mathrm{~mL}$ total coliform and 2 colonies per $100 \mathrm{~mL}$ E. coli (MPN method). The only sample that did not match was the nondetection of $E$. coli by the MF method, with 2 colonies per $100 \mathrm{~mL}$ E. coli detected by the MPN method. Because these samples only represent the extremes of the sampling results for bacteria, no conclusions could be determined about variability between methods. Both methods consistently agreed on nondetects.

Table 4. Comparison of replicate samples for bacteria using membrane filtration method and most probable number method for noncommunity supply wells in Pennsylvania

[>, greater than; <, less than]

\begin{tabular}{|c|c|c|c|c|}
\hline \multirow{2}{*}{ Site identifier } & \multicolumn{2}{|c|}{$\begin{array}{c}\text { Membrane filtration } \\
\text { method } \\
\text { (concentration } \\
\text { in colonies per } \\
100 \text { milliliters) }\end{array}$} & \multicolumn{2}{|c|}{$\begin{array}{c}\text { Most probable number } \\
\text { method } \\
\text { (concentration in } \\
\text { colonies per } \\
100 \text { milliliters) }\end{array}$} \\
\hline & $\begin{array}{l}\text { Total } \\
\text { coliform } \\
\text { (M-Endo } \\
\text { media) }\end{array}$ & $\begin{array}{c}\text { Escherichia } \\
\text { coli } \\
\text { (NA-MUG } \\
\text { media) }\end{array}$ & $\begin{array}{c}\text { Total } \\
\text { coliform } \\
\text { (Colilert } \\
\text { media) }\end{array}$ & $\begin{array}{c}\text { Escherichia } \\
\text { coli } \\
\text { (Colilert } \\
\text { media) }\end{array}$ \\
\hline 410453077284801 & $>80$ & $<1$ & 200 & 2 \\
\hline 395808076191801 & $<1$ & $<1$ & $<1$ & $<1$ \\
\hline 395945076030301 & $<1$ & $<1$ & $<1$ & $<1$ \\
\hline 402101077211801 & $<1$ & $<1$ & $<1$ & $<1$ \\
\hline 400525076224601 & $<1$ & $<1$ & $<1$ & $<1$ \\
\hline 414554076245301 & $<1$ & $<1$ & $<1$ & $<1$ \\
\hline 414617076435801 & $<1$ & $<1$ & $<1$ & $<1$ \\
\hline 413933076152901 & $<1$ & $<1$ & $<1$ & $<1$ \\
\hline
\end{tabular}




\section{MICROBIOLOGICAL QUALITY OF GROUND WATER USED FOR NONCOMMUNITY WATER SUPPLY}

Viruses and bacteria were detected in a small percentage of the wells sampled. Comparisons were made to determine whether or not occurrence of pathogens and indicator organisms differed in waters from the two major aquifers (carbonate and crystalline). Detections of the pathogens and indicator organisms were tested for statistical relations to land cover surrounding the wells and factors such as well depth (appendix 1). Occurrence of indicator organisms was compared to occurrence of pathogens to determine whether or not those organisms were good indicators of the occurrence of pathogens.

\section{Results of Indicator Organism and Pathogen Sampling}

A major objective of this study was to determine the occurrence and distribution of viruses, other pathogens, and indicator organisms in the study area. Of the pathogens and indicator organisms analyzed, results of sampling show a small percentage of detections. The spatial distribution of detections of viruses and $H$. pylori is shown in figures 4 and 5, respectively. The spatial distribution of the indicator organisms is shown in figures 6 to 11, respectively. The data are summarized in appendix 2. Out of 59 well samples analyzed, culturable viruses were detected in 8 percent of the wells ( 5 wells), H. pylori in 7 percent of the wells (4 wells), E. coli in 12 percent of the wells ( 7 wells), total coliform in 46 percent of the wells (27 wells), C. perfringens in 15 percent of the wells (9 wells), somatic coliphage in 8 percent of the wells ( 5 wells), male-specific coliphage in 5 percent of the wells ( 3 wells), and enterococcus in 14 percent of the wells (8 wells).
Of the five detections of culturable virus, two were near the lowest detection limit of 0.21 plaque forming units per $100 \mathrm{~L}$. Virus concentrations in the other three samples ranged from 18 to 56 plaque forming units per $100 \mathrm{~L}$. Detection limits on the 'nondetects' for the viruses vary on the basis of the volume of water filtered for the sample (appendix 1). As stated earlier, the volume sampled did not always reach the maximum volume because of practical considerations such as well capacity or owner cooperation. The effect of sample volume on the results was determined not to be a limiting factor. Although a greater sample volume would increase the probability of detecting a virus, the mean sample volume for the samples with virus detections actually was less than the mean sample volume for the samples without detections. The sample volume also was not biased towards any area of the study. Statistical comparisons (nonparametric Kruskal-Wallis test, $\mathrm{p}=0.84$ ) showed the sample volume in the areas underlain by carbonate bedrock was not significantly different than the sample volume in the areas underlain by crystalline bedrock. The virus type is not determined by the cell-culture method; however, most viruses detected by this method generally are considered enteric viruses that can cause intestinal distress or more serious illness. The water supplies that test positive for viruses must meet the treatment-technique criteria. This project did not sample finished water to determine the effectiveness of virus removal by treatment systems because this sampling was outside the scope of this project. Of the five locations where viruses were detected, four had disinfection systems in place at the time of sampling and the other has now installed a disinfection system. The virus detections were distributed evenly among the aquifers and showed no spatial pattern (fig. 4). 


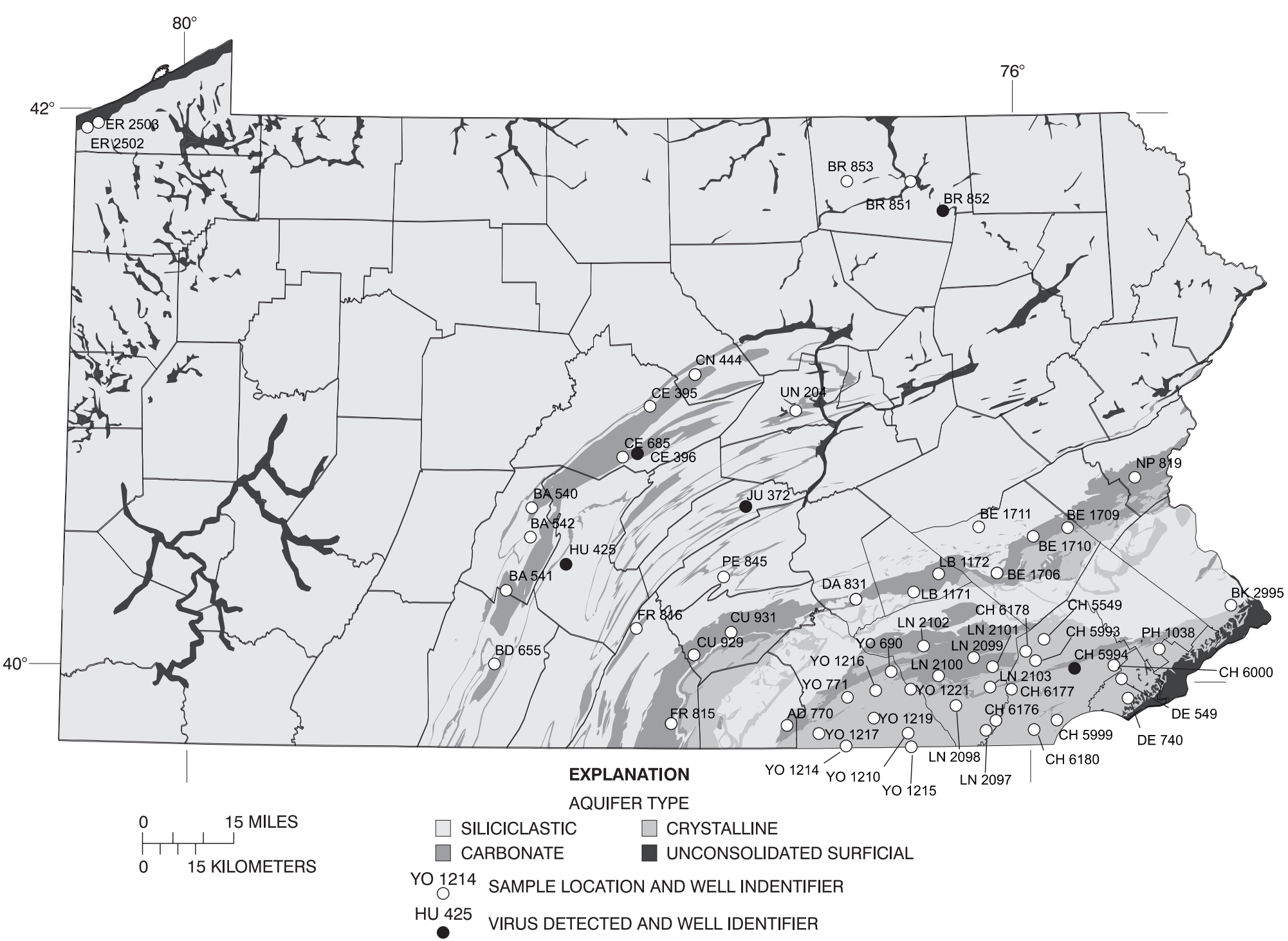

Figure 4. Sampling locations and detections of viruses in noncommunity supply wells in Pennsylvania. 


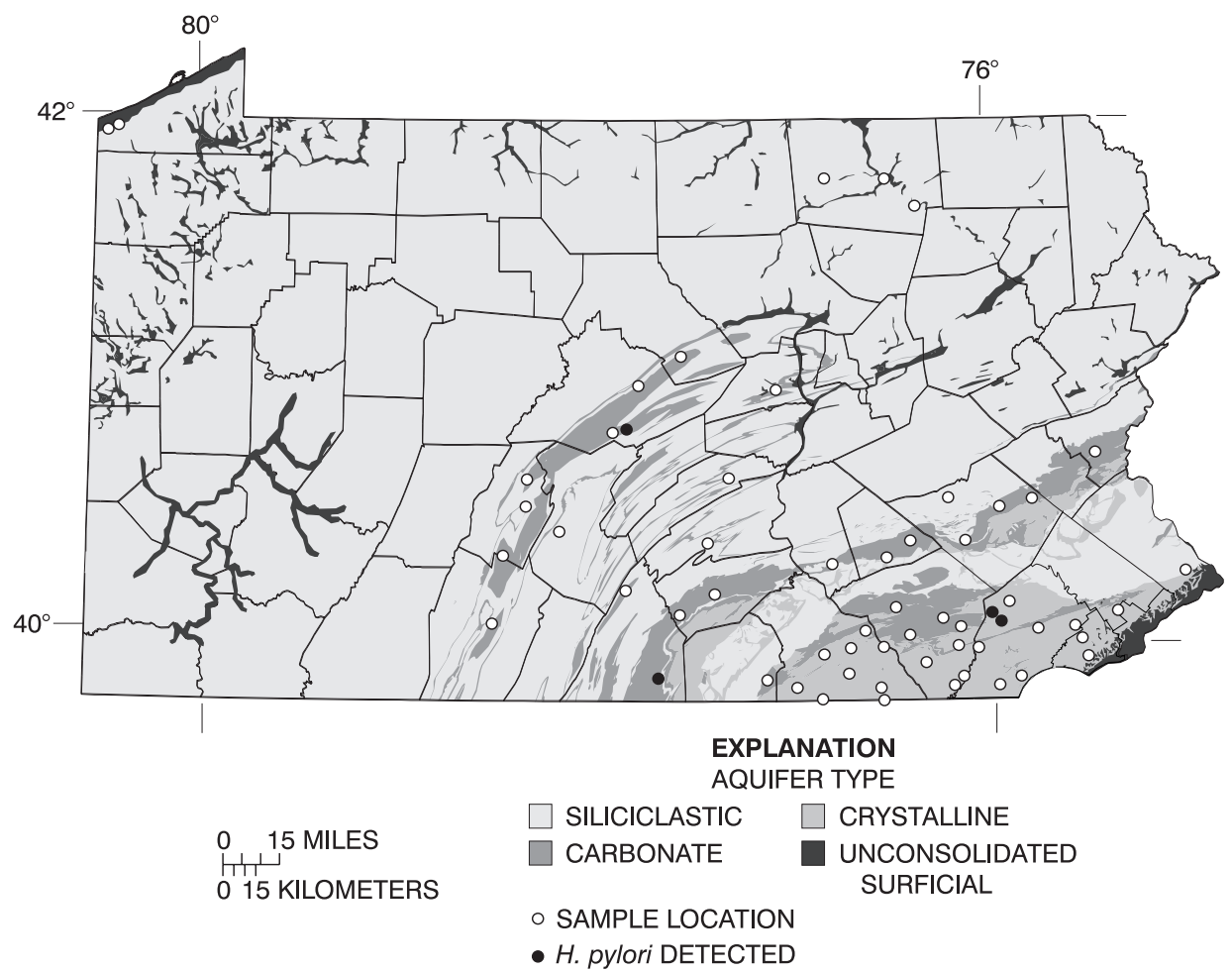

Figure 5. Sampling locations and detections of Helicobacter pylori in noncommunity supply wells in Pennsylvania.

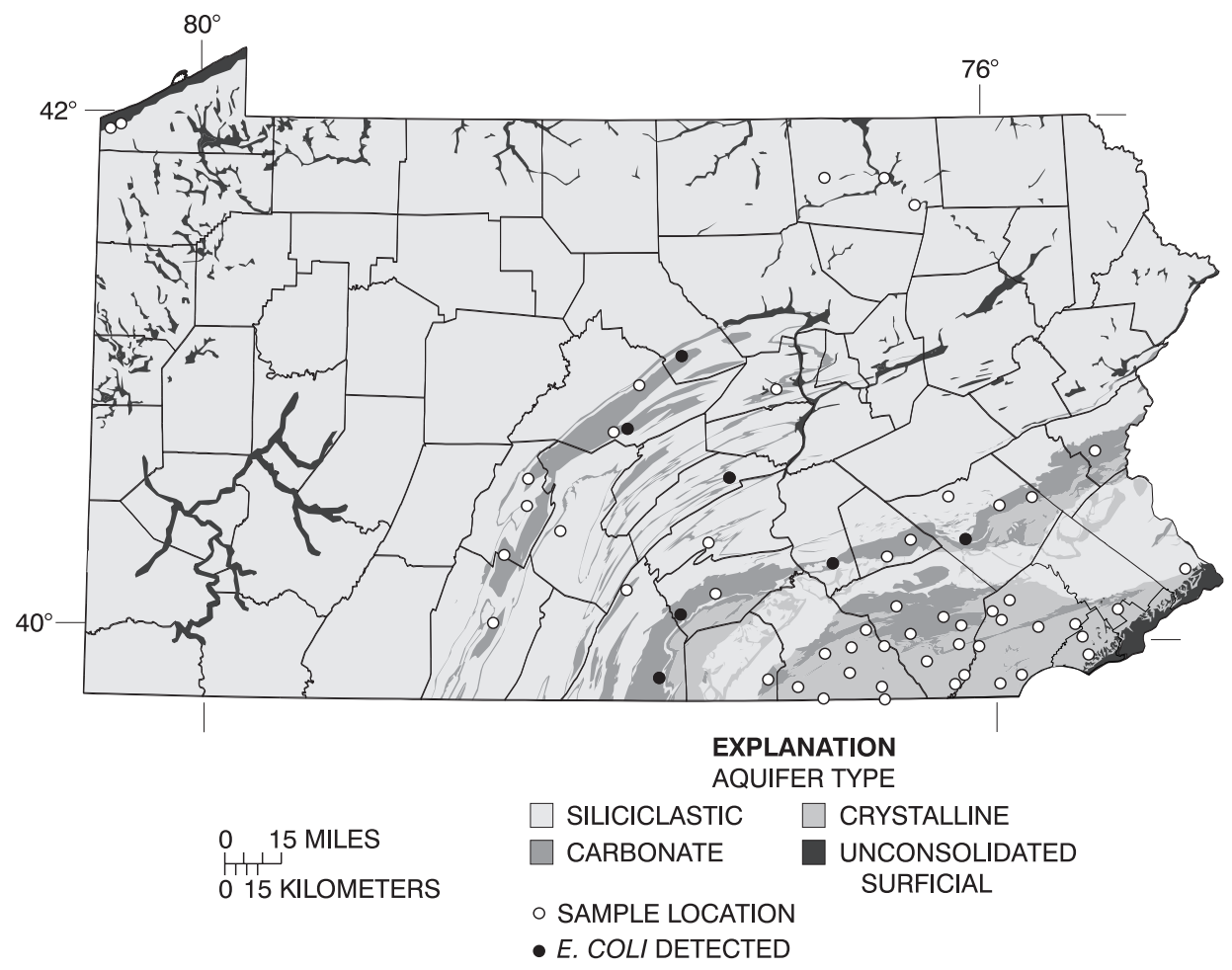

Figure 6. Sampling locations and detections of Escherichia coli in noncommunity supply wells in Pennsylvania. 


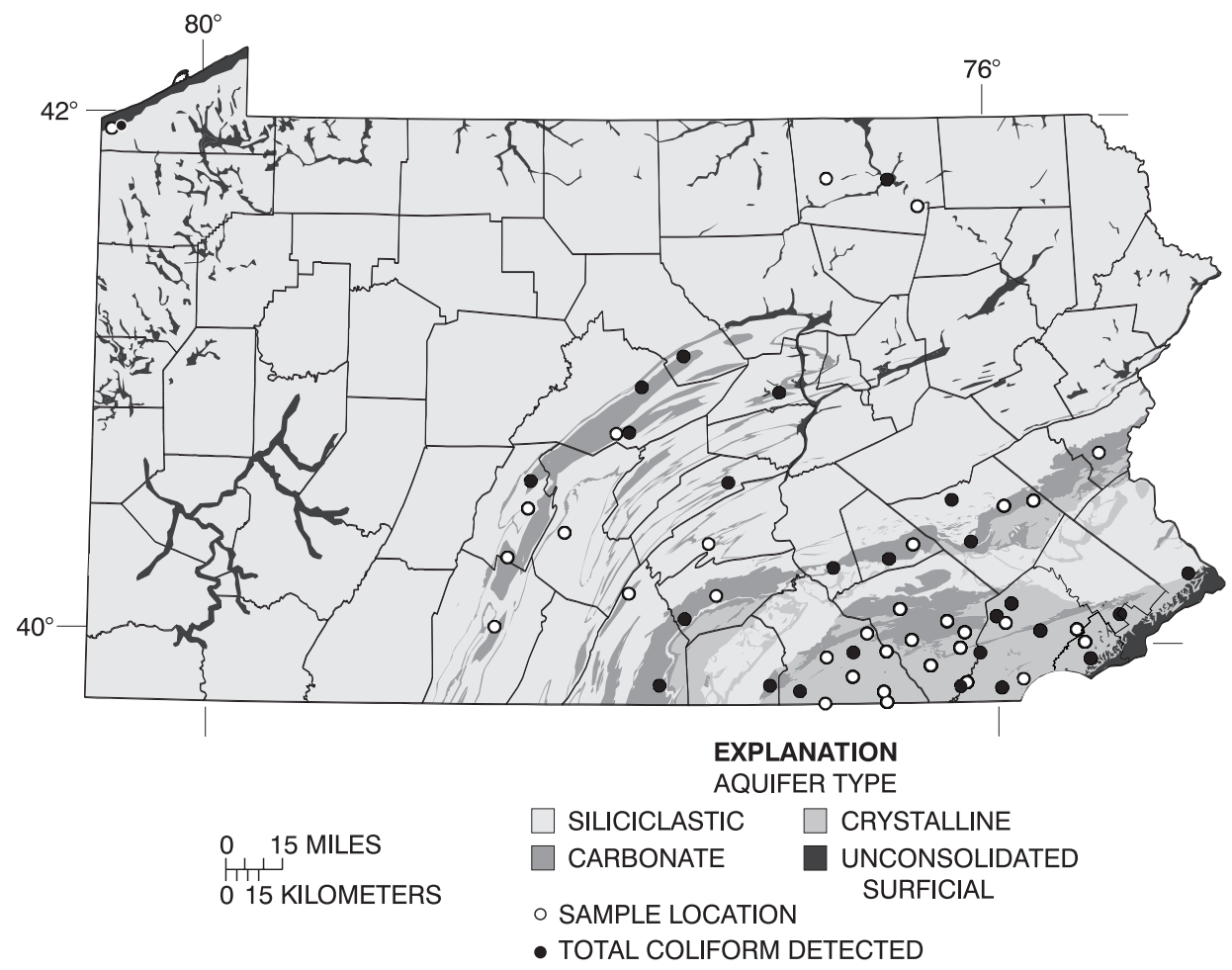

Figure 7. Sampling locations and detections of total coliform in noncommunity supply wells in Pennsylvania.

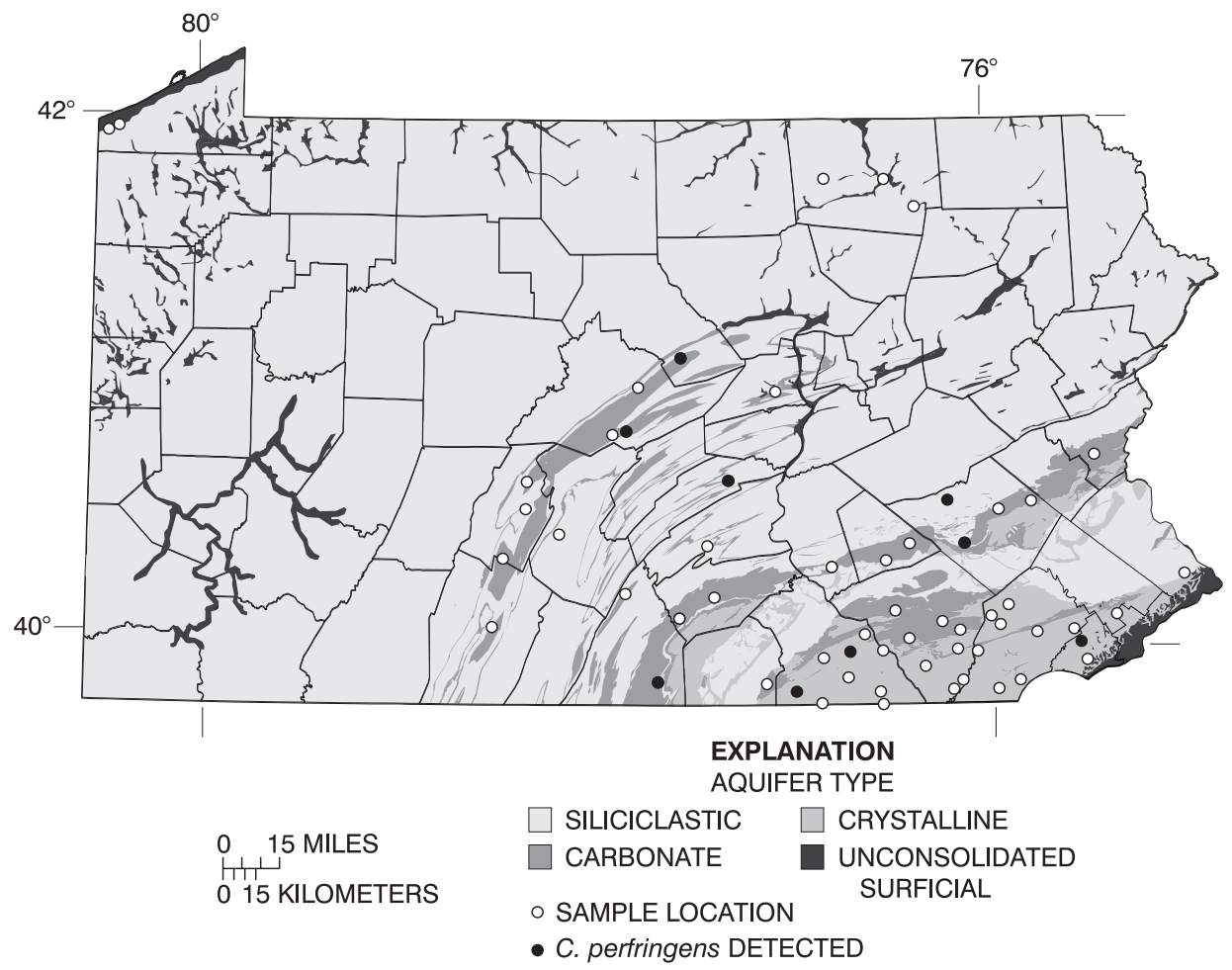

Figure 8. Sampling locations and detections of Clostridium perfringens in noncommunity supply wells in Pennsylvania. 


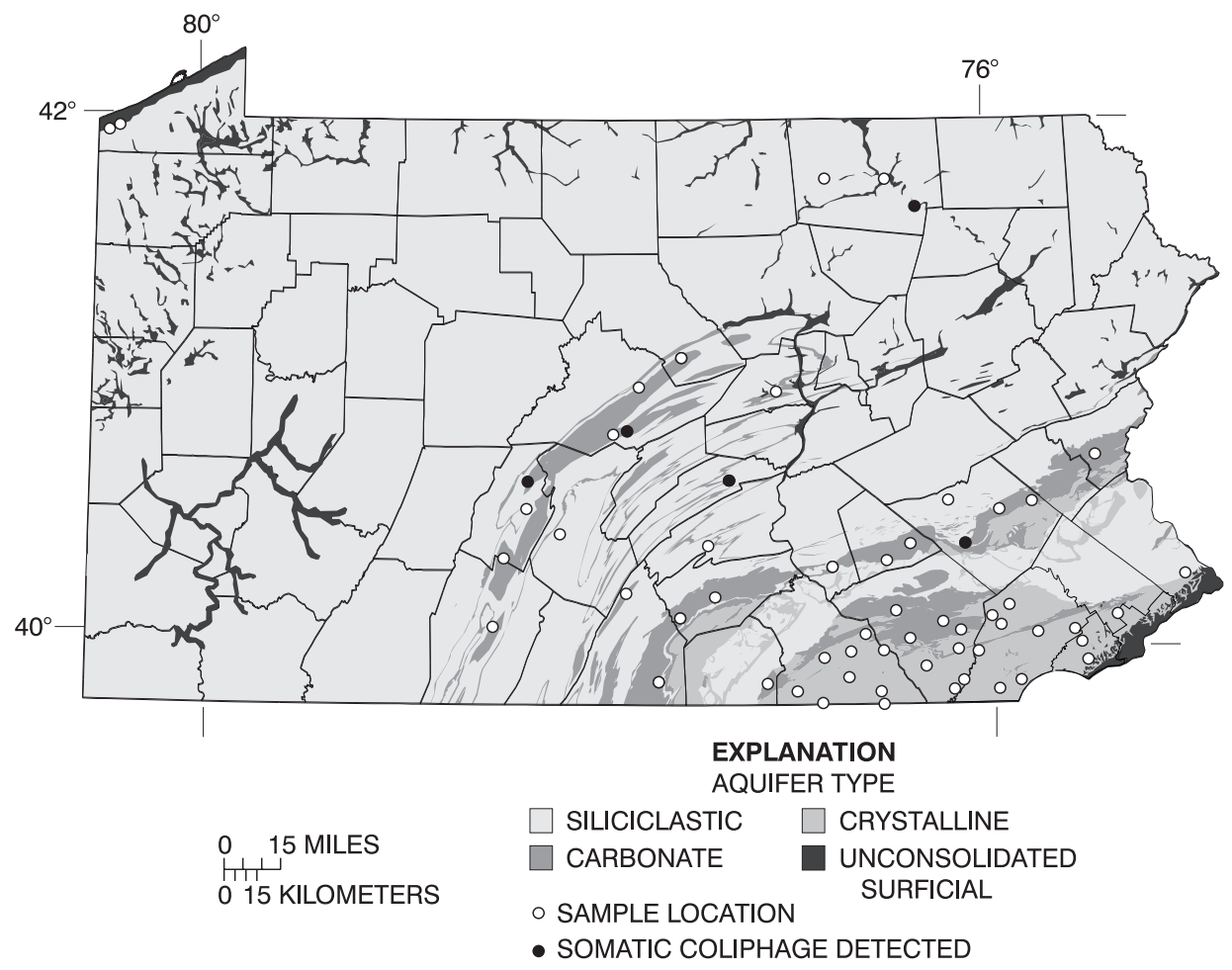

Figure 9. Sampling locations and detections of somatic coliphage in noncommunity supply wells in Pennsylvania.

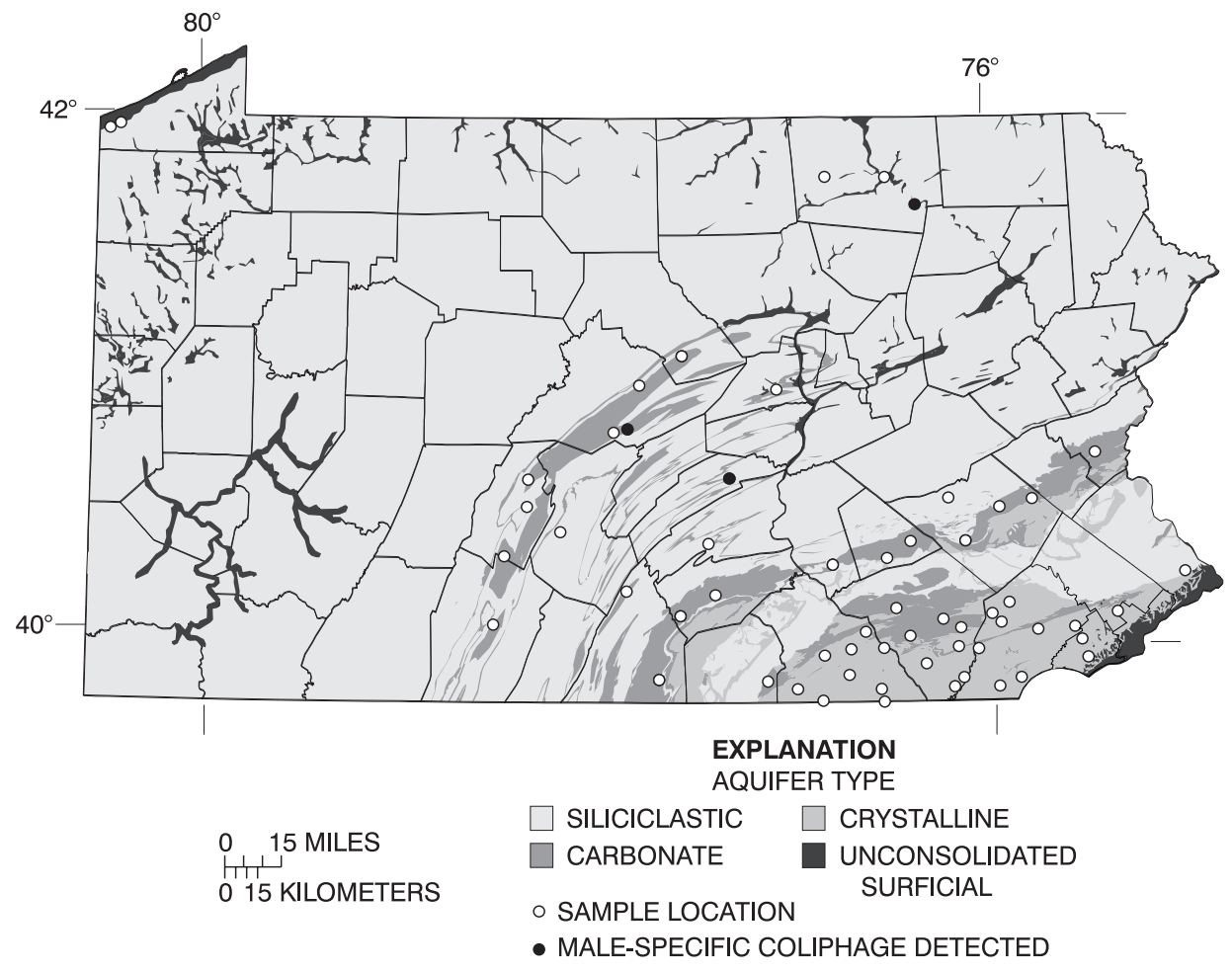

Figure 10. Sampling locations and detections of male-specific coliphage in noncommunity supply wells in Pennsylvania. 


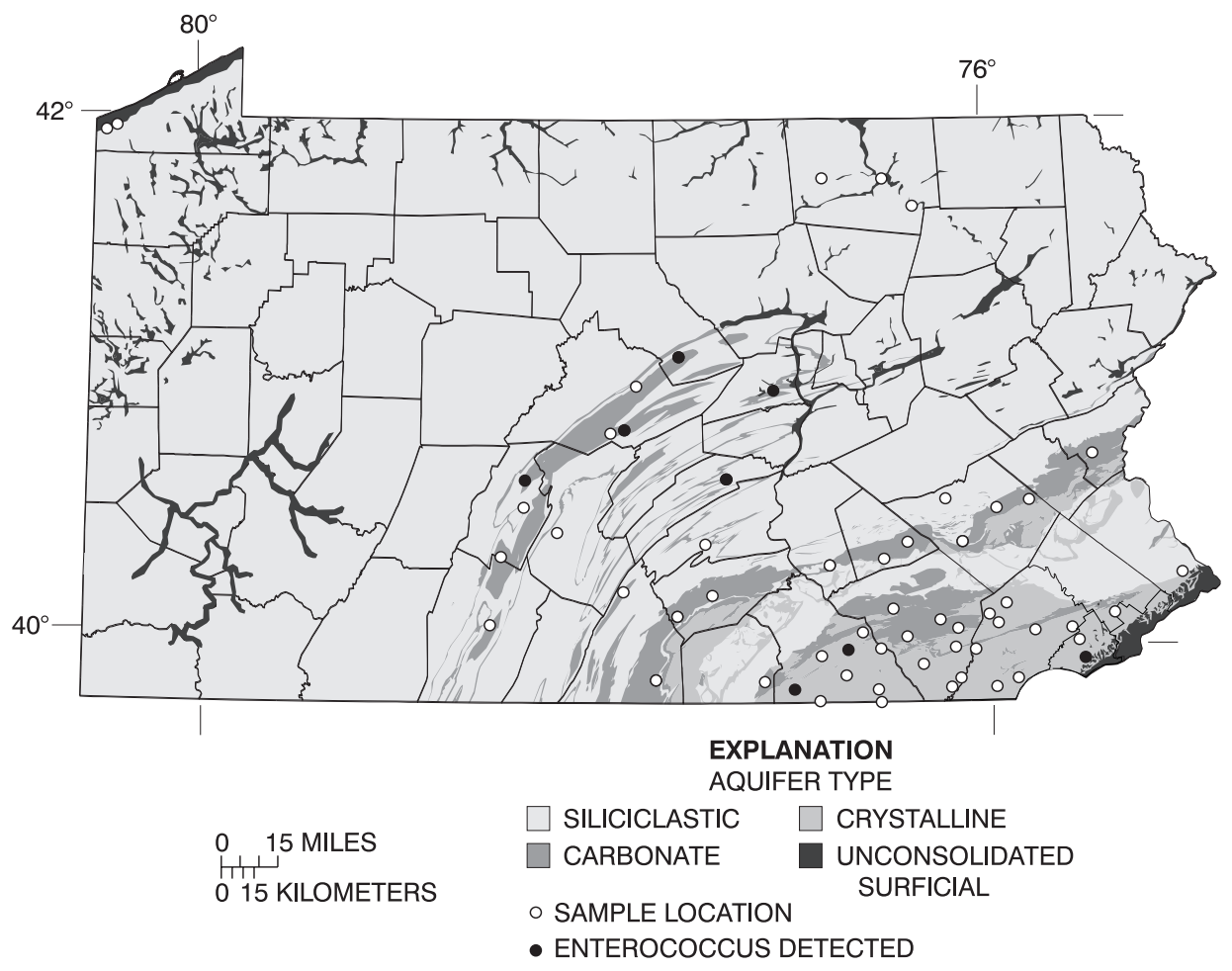

Figure 11. Sampling locations and detections of enterococcus in noncommunity supply wells in Pennsylvania.

\section{Factors Affecting Microbiological Quality of Ground Water}

Another objective of this study was to analyze the data with respect to the factors that affect the presence of microbiological contaminants in ground water. From previous studies, factors such as aquifer type, land use, well construction, and proximity to septic systems were determined to affect microbiological quality of ground water (Bickford and others, 1996). These factors were assessed in relation to the results of this study. Of the four aquifers assessed, two were sampled with sufficient density for statistical comparisons to be attempted. Those two aquifers were the carbonate aquifers and the crystalline aquifers. The other two aquifers were sampled for reconnaissance purposes and will be discussed in a general manner but not included in statistical comparisons.

The first comparisons among the pathogens and bacteria were by aquifer types. This comparison was done because of potential differences in contaminant transport among aquifer types. Samples collected in areas underlain by carbonate aquifers had a higher number of detections for all of the microbes analyzed except for $H$. pylori (table 5). Because of the number of nondetections in the data set, contingency tables were used to determine

Table 5. Number of detections of pathogens and indicator organisms by aquifer type for noncommunity supply wells in Pennsylvania

\begin{tabular}{lccccccccc}
\hline \multicolumn{1}{c}{ Aquifer type } & $\begin{array}{c}\text { Number } \\
\text { of } \\
\text { samples }\end{array}$ & $\begin{array}{c}\text { Virus } \\
\text { detec- } \\
\text { tions }\end{array}$ & $\begin{array}{c}\text { Helicobacter } \\
\text { pylori }\end{array}$ & $\begin{array}{c}\text { Total } \\
\text { coliform }\end{array}$ & $\begin{array}{c}\text { Escherichia } \\
\text { coli }\end{array}$ & $\begin{array}{c}\text { Clostridium } \\
\text { perfringens }\end{array}$ & Enterococcus & $\begin{array}{c}\text { Somatic } \\
\text { coliphage }\end{array}$ & $\begin{array}{c}\text { Male- } \\
\text { specific } \\
\text { coliphage }\end{array}$ \\
\hline Carbonate & 25 & 2 & 2 & 13 & 7 & 6 & 5 & 4 & 2 \\
Crystalline & 25 & 1 & 2 & 11 & 0 & 2 & 3 & 0 & 0 \\
Siliciclastic & 5 & 1 & 0 & 2 & 0 & 1 & 0 & 0 & 0 \\
Unconsolidated & 5 & 1 & 0 & 1 & 0 & 0 & 0 & 1 & 1 \\
\hline
\end{tabular}


whether or not the differences in the detection rate between the carbonate and crystalline aquifers were statistically significant. The contingency-table analysis requires an expected value of greater than five for at least 80 percent of the cells (Helsel and Hirsch, 1992); therefore, even contingency tables were not a valid test for most of the microorganisms. The null hypothesis was that occurrence of the pathogens and indicators were not significantly different between carbonate and crystalline aquifers. The results of the contingency-table analysis for total coliform (the only organism that met the expected value criteria) showed that differences in the detection rates among the two aquifer types were not statistically significant at an alpha value of 0.05 .

Comparisons of occurrence of the various microbes to land cover surrounding the well also were conducted. Sources of the pathogens and indicator organisms vary among land-cover types, therefore, land cover is a potential explanatory variable that could describe differences in occurrence of the pathogens and indicators. Logistic regression was used to test whether categorical variables of detect and nondetect had significantly different percentages of a given land cover in the area surrounding the well. An alpha value of 0.05 for both the regression and the parameter was used to determine if a relation was statistically sig- nificant. The approach was to compare the percentage of a land cover (Vogelmann and others, 1998a; Vogelmann and others, 1998b) within a 1,500-ft radius of the wells with detections of microorganisms to the percentage of that same land cover around wells where no microbes were detected (table 6). The only statistically significant regressions were for wells with detections of $H$. pylori. Overall, the regression had a p-value of less than 0.05 for both agricultural and urban land cover; however, the $\mathrm{p}$-values of the individual land-cover parameters for those regressions exceeded 0.05 . The $\mathrm{p}$-value for the agricultural land-cover parameter of 0.07 indicates wells with detections of $H$. pylori had a significantly lower percentage of agricultural land (row crop and hay and pasture) in a 1,500-ft radius than those wells with no $H$. pylori detected at a 93-percent confidence interval. This means there is a 93-percent chance an association is present mathematically between the variables being compared. The land-cover percentages in table 6 illustrate this difference as well. This result is expected because the source of $H$. pylori would primarily be a human host and its occurrence would not be expected to be related to agricultural land cover. The results of all other tests showed the average percentage of agricultural land around a well with detections of microbes

Table 6. Summary statistics of land cover in a 1,500-foot radius of noncommunity supply wells in Pennsylvania categorized by detections and nondetections of organisms and results of logistic regression comparing occurrence of pathogens and indicator organisms among land covers within a 1,500-foot radius of the wells

[Probabilities less than 0.05 for both the regression and the parameter indicate a statistically significant relation]

\begin{tabular}{|c|c|c|c|c|c|c|c|c|c|}
\hline \multirow[b]{2}{*}{ Microorganism } & \multicolumn{2}{|c|}{$\begin{array}{l}\text { Average percentage } \\
\text { of agricultural land } \\
\text { within 1,500-foot } \\
\text { radius of the well }\end{array}$} & \multirow{2}{*}{$\begin{array}{l}\text { Prob- } \\
\text { ability } \\
\text { for } \\
\text { regression } \\
\text { (prob- } \\
\text { ability } \\
\text { for para- } \\
\text { meter) }\end{array}$} & \multicolumn{2}{|c|}{$\begin{array}{l}\text { Average percentage } \\
\text { of forested land } \\
\text { within 1,500-foot } \\
\text { radius of the well }\end{array}$} & \multirow{2}{*}{$\begin{array}{l}\text { Prob- } \\
\text { ability } \\
\text { for } \\
\text { regression } \\
\text { (prob- } \\
\text { ability } \\
\text { for para- } \\
\text { meter) }\end{array}$} & \multicolumn{2}{|c|}{$\begin{array}{l}\text { Average percentage } \\
\text { of urban land } \\
\text { within } 1,500 \text {-foot } \\
\text { radius of the well }\end{array}$} & \multirow{2}{*}{$\begin{array}{l}\text { Prob- } \\
\text { ability } \\
\text { for } \\
\text { regression } \\
\text { (prob- } \\
\text { ability } \\
\text { for para- } \\
\text { meter) }\end{array}$} \\
\hline & Detected & $\begin{array}{c}\text { Not } \\
\text { detected }\end{array}$ & & Detected & $\begin{array}{c}\text { Not } \\
\text { detected }\end{array}$ & & Detected & $\begin{array}{c}\text { Not } \\
\text { detected }\end{array}$ & \\
\hline Virus & 50 & 64 & 0.31 & 39 & 27 & 0.41 & 1 & 4 & 0.25 \\
\hline Total coliform & 60 & 65 & .44 & 31 & 26 & .52 & 4 & 4 & .70 \\
\hline Escherichia coli & 70 & 62 & .50 & 16 & 30 & .21 & 4 & 4 & .87 \\
\hline $\begin{array}{l}\text { Clostridium } \\
\text { perfringens }\end{array}$ & 66 & 63 & .78 & 25 & 29 & .65 & 3 & 4 & .53 \\
\hline Enterococcus & 71 & 61 & .42 & 16 & 30 & .17 & 2 & 4 & .41 \\
\hline Somatic coliphage & 66 & 63 & .80 & 14 & 30 & .21 & 1 & 6 & .43 \\
\hline $\begin{array}{c}\text { Male-specific } \\
\text { coliphage }\end{array}$ & 64 & 63 & .96 & 17 & 29 & .46 & 2 & 4 & .48 \\
\hline Helicobacter pylori & 38 & 65 & $\begin{array}{l}.05 \\
(.07)\end{array}$ & 51 & 27 & .07 & 1 & 4 & $\begin{array}{l}.04 \\
(.24)\end{array}$ \\
\hline
\end{tabular}


was not significantly different than the percentage of agricultural land around wells without detections. This same approach was used for urban land (a combination of high-density residential, commercial and industrial, and low-density residential land cover). With the exception of $H$. pylori, no statistically significant differences in urban landcover percentages were observed for any of the pathogens or indicators when the wells with detections and wells with no detections were compared. For forested land cover (deciduous forest, coniferous forest, and mixed forest) again, there were no significant differences among wells with detections of pathogens or indicators and wells without detections.

The general lack of relation between land cover and detections of the pathogens and indicator organisms was a departure from the findings of Bickford and others (1996) of domestic wells in this same area. The design, however, was different than the National Water-Quality Assessment (NAWQA) study of Bickford and others. In the NAWQA study, site selection was targeted so that a well was solely representative of a single land cover and this study contained wells with a mix of agricultural, urban, and forested land cover near each well. It would be expected that a design with sharper contrasts among groups would find more differences. It is still noteworthy, however, that detections of these organisms had no statistically significant positive relation to agricultural land cover and no negative correlation to forested land cover. One possible explanation for this is that contaminants detected in this study originated within $100-200 \mathrm{ft}$ of the well (the typical distance to the nearest septic system) rather than within the 1,500-ft radius. This study took place during the fall and early winter when manure application was neither prevalent nor recent. The NAWQA study took place in the early summer, immediately following the major manure application period. It is possible the effect of agricultural application of manure on microbiological water quality is seasonal in nature. This effect would leave septic systems as a primary, year-round source of pathogens and indicators.

Other comparisons between the presence of pathogens and indicators and variables such as well depth, well age, proximity to septic systems, and public sewers and on-lot septic were attempted. However, some comparisons could not be made because of lack of data. Information on well depth was available for 39 of the 59 wells, and logistic regression between well depths in water from wells with and without detections showed no statistically significant relations (table 7) at an alpha value of 0.05 . Well age was available for only 7 of the 59 wells. Septic tanks, leach fields, or pit latrines were present within a $300-\mathrm{ft}$ radius of each well. The specific location of leach fields with respect to the wells was determined for most sites; however, the exact location of buried septic tanks and sewage lines was not determined. Because of the uncertainty of these specific locations and the lack of variation in the sources (nearly all septic systems were between 75 and $150 \mathrm{ft}$ from the well), it was determined that statistical comparisons of these variables would not be conducted.

Table 7. Results of logistic regression comparing occurrence of pathogens and indicator organisms to well depths for noncomunity supply wells in Pennsylvania

[ $\mathrm{n}=$ number of samples; probabilities less than 0.05 indicate statistically significant relations]

\begin{tabular}{lccc}
\hline & \multicolumn{2}{c}{$\begin{array}{c}\text { Probability that well depth is } \\
\text { related to occurrence }\end{array}$} \\
\cline { 2 - 4 } \multicolumn{1}{c}{ Microorganism } & $\mathbf{n}$ & $\begin{array}{c}\text { Regression } \\
\text { probability }\end{array}$ & $\begin{array}{c}\text { Parameter } \\
\text { probability }\end{array}$ \\
\hline Virus & 39 & 0.35 & 0.37 \\
Total coliform & 39 & .91 & .91 \\
Escherichia coli & 39 & .25 & .27 \\
Clostridium perfringens & 39 & .89 & .89 \\
Enterococcus & 39 & .24 & .23 \\
Somatic coliphage & 39 & .33 & .34 \\
Male-specific coliphage & 39 & .87 & .36 \\
Helicobacter pylori & 39 & .23 & .25 \\
\hline
\end{tabular}

In one case of a virus detection, the owner of the property determined that a septic tank approximately $60 \mathrm{ft}$ from the well was leaking at the time of the sampling in December 2000. Although the tank has since been repaired, it was probably the source of the virus detected at that site. Unknown factors such as the functioning of septic tanks, pipes, and leach fields could be important in the virus detections and may explain the lack of a statistical relation between viruses and land cover. 


\section{Relations Between Indicator Bacteria and Pathogens in Ground Water}

A final objective of this study was to compare the indicator organisms to pathogen detections on a site-by-site basis to make observations on the usefulness of indicator bacteria. First, statistical comparisons between the pathogens and indicators were attempted using contingency tables. Because more than half of each of the data sets contained nondetects, linear correlations would not be valid. The contingency tables again did not meet the required expected value of greater than five for at least 80 percent of the cells (Helsel and Hirsch, 1992); therefore, contingency tables were not a valid test either. Although no statistical test is available to quantify the relations between the pathogens and indicators, a simple summary of the co-occurrence is presented.

Results of the co-occurrence of pathogens and indicators are shown in table 8 . The results indicate male-specific and somatic coliphage had the best relation with culturable viruses. Both coliphages had a low overall occurrence percentage and a high co-occurrence with viruses. Total coliform also had co-occurrence with virus occurrence; however, total coliform also had the highest overall occurrence rate (45 percent) of all of the indicators. It is important to note that although single indicators were present in up to 60 percent of the samples that were positive for virus, at least one indicator organism was present in 80 percent of the samples with culturable virus. This result shows the importance of testing for multiple indicator organisms. Comparisons show that total coliform is an indicator organism that has a high co-occurrence with $H$. pylori. This table represents only the data collected in this study, and increasing the number of samples would add to the confidence in the relation between the indicators and pathogens.

Sample volume may have an effect on the cooccurrence of the indicators and the viruses. As shown on table 2 , up to $1,000 \mathrm{~L}$ of water was filtered for the virus sample, which is a much greater volume than the $100 \mathrm{~mL}$ samples for most indicator organisms. Only coliphage samples, which also are taken from the filter, have volumes similar to the virus samples. Although these are the recommended volumes (table 2) that typically would be sampled for regulatory compliance, comparisons between indicators and viruses must take
Table 8. Co-occurrence of indicator organisms and pathogens for noncommunity supply wells in Pennsylvania

\begin{tabular}{|c|c|c|c|}
\hline \multirow[t]{3}{*}{ Indicator organism } & \multirow{3}{*}{$\begin{array}{c}\text { Overall } \\
\text { occurrence } \\
\text { percentage }\end{array}$} & \multirow{2}{*}{\multicolumn{2}{|c|}{$\begin{array}{c}\text { Percentage of time } \\
\text { indicator was } \\
\text { detected when } \\
\text { pathogen was } \\
\text { present } \\
\text { Pathogen }\end{array}$}} \\
\hline & & & \\
\hline & & Virus & $\begin{array}{c}\text { Helicobacter } \\
\text { pylori }\end{array}$ \\
\hline Total coliform & 45 & 60 & 75 \\
\hline Escherichia coli & 12 & 40 & 50 \\
\hline Enterococcus & 13 & 40 & 25 \\
\hline Clostridium perfringens & 15 & 40 & 50 \\
\hline Male-specific coliphage & 5 & 60 & 25 \\
\hline Somatic coliphage & 8 & 60 & 25 \\
\hline At least one indicator & 48 & 80 & 75 \\
\hline
\end{tabular}

these differences in sample volume into consideration. Larger sample volumes could change the results significantly.

The usefulness of an indicator organism is not defined solely by its statistical relation to the pathogen it is supposed to represent. For example, it is important and useful to know that coliphage showed a good relation with virus occurrence; however, this relation alone does not make coliphage a good indicator organism. An indicator organism should not only be more inexpensive to detect, but it should be equal to or more abundant in the environment and have a die-off rate equal to or slower than the pathogen it represents. If this is the case, an ideal indicator would be present in every sample with the pathogen, although the converse may not be the case. Data from this study show that, for both viruses and H. pylori, the indicator organisms were not 'ideal' indicators. Some observations of individual cases help highlight that issue.

Using total coliform and E. coli as screening tools, two of the five sites where viruses were detected appeared to have passed the drinkingwater standards. Neither total coliform nor E. coli were detected at all in two of the samples where viruses were detected. In one of these cases, coliphage was detected and would have been a useful additional tool; however, in the other case, none of the selected indicator organisms were detected. $H$. pylori also was detected in a well that tested negative for both total coliform and E. coli. It appears that, although some screening tools may 
be available to help determine pathogen occurrence, none of the individual indicator organisms would be an ideal surrogate for virus or $H$. pylori occurrence and analyzing for multiple indicator organisms increases the effectiveness of the screening process.

Although the indicators were not always present in samples from wells where viruses were detected, it appears that high numbers of E. coli present indicate potential presence of viruses. Of the seven samples where E. coli were detected, five samples had detections at the low end of the range (less than 4 colonies per $100 \mathrm{~mL}$ ). The two samples with $E$. coli detected in a higher range (27 and 56 colonies per $100 \mathrm{~mL}$ ) were at sites that had the highest virus counts. In fact, these sites had detections of every indicator organism, and total coliform concentrations were too numerous to count at both of these sites. This result probably is a good illustration of why the total coliform and E. coli bacteria are still useful as indicator organisms and certainly more desirable because testing for pathogens is both costly and labor intensive in comparison.

\section{SUMMARY AND CONCLUSIONS}

Sampling of 59 noncommunity water supplies in the Commonwealth of Pennsylvania was done as part of a cooperative effort between the U.S. Geological Survey and PaDEP Bureau of Water Supply and Wastewater Management. Detections were observed for all the pathogens and microbiological indicator organisms analyzed. The detection rate of total coliform was 46 percent; however, all the other microorganisms analyzed had detection rates of less than 15 percent. E. coli was detected in 12 percent of the wells, H. pylori in 7 percent of the wells, enterococcus in 14 percent of the wells, C. perfringens in 15 percent of the wells, somatic coliphage in 8 percent of the wells, malespecific coliphage in 5 percent of the wells, and culturable viruses in 8 percent of the wells. Viruses were detected in all four of the aquifers where samples were collected (carbonate, crystalline, siliciclastic, and unconsolidated surficial).

Statistical tests were conducted to determine the factors related to the occurrence of these pathogens and indicator organisms. Because the presence of one pathogen can be a detriment to human health, the statistical tests chosen compared presence and absence rather than the concentration of the contaminants. Carbonate aquifers tended to have a greater number of detections for the pathogens and indicators sampled than the crystalline aquifers; however, statistical tests were not valid for most of the organisms. These differences in the number of detections in samples from carbonate and crystalline aquifers were not statistically significant for total coliform bacteria. The detection of viruses in both the siliciclastic and unconsolidated surficial aquifers cannot be evaluated statistically without additional sampling. Statistical tests conducted comparing the percentage of various land covers within a 1,500-ft radius around the well showed no significant relation between land cover and occurrence of the microorganisms. Detections of the pathogens and indicator organisms were not statistically related to the amounts of urban, agricultural, or forested areas surrounding the well. The lack of a relation between occurrence and land cover may be the result of the time of year when the sampling was conducted and that septic systems were at virtually all the sites. Detections of the pathogens and indicator organisms were not related to well depth either. Factors such as proximity to septic systems were not evaluated; however, one site with a virus detection was found to have a leaking septic system. Although the project was designed so that statistical comparisons could be made, the overall low detection rate made these comparisons invalid in many cases. In cases where statistical comparisons could be made, the low number of detections made it difficult to determine significant relations. With such a low detection frequency, a higher number of samples would be needed for statistical analysis to determine significant differences and relations if present.

Comparisons of the pathogens to the indicator organisms were made to determine how the indicators performed as predictive tools. Although none of the pairs of organisms had sufficient numbers of detections for statistical comparisons, the co-occurrence of organisms was observed. Somatic and male-specific coliphage and total coliform showed the highest co-occurrence with viruses. E. coli, total coliform, and C. perfringens showed the best relation to $H$. pylori. However, viruses and $H$. pylori were each detected in one well in which no indicator organisms were present; therefore, none of the indicator organisms sampled provided complete assurance of pathogen-free water when used as a screening tool. 


\section{REFERENCES CITED}

Abbaszadegan, M., Stewart, P.W., LeChevalier, M.W., Rosen, J.S., and Gerba, C.P., 1998, Occurrence of viruses in ground water in the United States-Interim report: Belleville, Ill., American Water Works Service Company, $157 \mathrm{p}$.

American Society for Testing and Materials (ASTM), 2000, Standard test method for enterococci in water using Enterolert in ASTM standards on water and environmental technology, section 11: Philadelphia, ASTM [variously paginated].

Berg, T.M., Edmunds, W.E., Geyer, A.R., Glover, A.D., Hoskins, D.M., MacLachlan, D.B., Root, S.I., Sevon, W.D., and Socolow, A.A., comps., 1980, Geologic map of Pennsylvania:

Pennsylvania Geological Survey, 4th ser., scale 1:250,000, 2 sheets.

Bickford, T.M., Lindsey, B.D., and Beaver, M.R., 1996, Bacteriological quality of ground water used for household supply, Lower

Susquehanna River Basin, Pennsylvania and Maryland: U.S. Geological Survey WaterResources Investigations Report 96-4212, 31 p.

Buckwalter, T.F., Schreffler, C.L., and Gleichsner, R.E., 1996, Geohydrology and water quality of the unconsolidated deposits in Erie County, Pennsylvania: U.S. Geological Survey WaterResources Investigations Report 95-4165, $105 \mathrm{p}$.

Clesceri, L.S., Greenberg, A.E., and Eaton, A.D., eds., 1998, Enzyme substrate coliform test in Standard methods for the examination of water and wastewater (20th ed).: Washington D.C., American Public Health Association, p. 9-68.

Fishel, D.K., and Lietman, P.L., 1986, Occurrence of nitrate and herbicides in ground water in the Upper Conestoga River Basin, Pennsylvania: U.S. Geological Survey Water-Resources Investigations Report 85-4202, 8 p.

Francy, D.S., Myers, D.N., and Helsel, D.R., 2000, Microbiological monitoring for the U.S. Geological Survey National Water-Quality Assessment Program: U.S. Geological Survey Water-Resources Investigations Report 00-4018, $34 \mathrm{p}$.
Gerba, C.P., 1984, Applied and theoretical aspects of virus adsorption to surfaces: Applied Microbiology, v. 30, p. 133-168.

Hegarty, J.P., Dowd, M.T., and Baker, K.H., 1999, Occurrence of Helicobacter pylori in surface water in the United States: Journal of Applied Microbiology, v. 87, p. 697-701.

Helsel, D.R., and Hirsch, R.M., 1992, Statistical methods in water resources: New York, Elsevier Science Publishing Company Inc., p. 217-18.

Horsburgh, C.R., Jr., and Nelson, A.M. eds., 1997, Pathology of emerging infections: Washington, D.C., ASM Press, p. 227-228.

Keswick, B.H., and Gerba, C.P., 1980, Viruses in ground water: Environment and Technology, v. 14 , no. 11 , p. 1,290-1,297.

Lindsey, B.D., and Bickford, T.M., 1999, Hydrogeologic framework and sampling design for and assessment of agricultural pesticides in ground water in Pennsylvania: U.S. Geological Survey Water-Resources Investigations Report 99-4076, 44 p.

Lindsey, B.D., Loper, C.A., and Hainly, R.A., 1997, Nitrate in ground water and stream base flow in the Lower Susquehanna River Basin, Pennsylvania and Maryland: U.S. Geological Survey Water-Resources Investigations Report 97-4146, 66 p.

Macler, B.A., 1996, Developing the ground water disinfection rule: Journal American Water Works Association, v. 88, no. 3, p. 47-55.

Randall, A.D., 1970, Movement of bacteria from a river to a municipal well-A Case History: Journal American Water Works Association, v. 62 , no. 11 , p. $716-720$.

Risser, D.W., and Siwiec, S.F., 1996, Environmental setting of the Lower Susquehanna River Basin: U.S. Geological Survey WaterResources Investigations Report 94-4245, 70 p., 23 supp. maps, 3 pls.

SAS Institute, 1990, SAS user's guide-The logistic procedure-Version 6 (4th ed.): Cary, N.C., SAS Institute Pub., p. 1,071-1,126. 


\section{REFERENCES CITED-Continued}

Scott, J.C., 1990, Computerized stratified random site-selection approaches for design of a ground-water-quality sampling network: U.S. Geological Survey Water-Resources Investigations Report 90-4101, 109 p.

Shindel, H.L., Mangus, J.P., and Trimble, L.E., 1999, Water resources data, Ohio, water year 1999, vol. 2, St. Lawrence River Basin and Statewide Project Data: U.S. Geological Survey WaterData Report OH 99-2, 313 p.

Soller, D.R., and Packard, P.H., 1998, Digital representation of a map showing the thickness and character of quaternary sediments in the glaciated United States east of the Rocky Mountains: U.S. Geological Survey Digital Data Series DDS-38, one CD-ROM.

Susquehanna River Basin Coordinating Committee, 1970, Susquehanna River Basin study, Supplement B-Project Summary.

U.S. Environmental Protection Agency, 1991, Test methods for Escherichia coli in drinking water: Cincinnati, Ohio, EPA/600/4-91/016.

1996, Information collection rule microbial laboratory manual: Washington, D.C., EPA/600/R-95/178. 2000a, National primary drinking water regulations: Washington, D.C., Federal Register, 40 CFR Ch I. (7-1-00 ed.), p. 334-561.

2000b, National primary drinking water regulations-Ground water rule; Proposed rules: Washington, D.C., Federal Register, 40 CFR Parts 141 and 142 [WH-FRL-6584-4] RIN 2040-AA97, p. 30,194-20,274.

Viessman, W., Jr., and Hammer, M.J., 1985, Water supply and pollution control (4th ed.): New York, Harper and Row, p. 219.

Vogelmann, J.E., Sohl, T., and Howard, S.M., 1998a, Regional characterization of land cover using multiple sources of data: Photogrammetric Engineering and Remote Sensing, v. 64, p. 4557.

Vogelmann, J.E., Sohl, T.L., Campbell, P.V., and Shaw, D.M., 1998b, Regional land cover characterization using landsat thematic mapper data and ancillary data sources: Environmental Monitoring and Assessment, v. 51, p. $415-428$.

Walsh, James, and Major, Yarta, 2000, Minnesota Department of Health viral occurrence study: St. Paul, Minn., Minnesota Department of Health, 162 p. 


\section{APPENDIXES}


Appendix 1. Noncommunity supply well information for Pennsylvania

[USGS, U.S. Geological Survey; Aquifer type codes: $\mathrm{C}=$ Carbonate, $\mathrm{CR}=$ Crystalline, $\mathrm{S}=$ Siliciclastic; U, Unconsolidated; --, no data]

\begin{tabular}{|c|c|c|c|c|c|c|c|c|c|c|}
\hline \multirow[b]{2}{*}{$\begin{array}{l}\text { USGS site } \\
\text { identification } \\
\text { number }\end{array}$} & \multirow[b]{2}{*}{$\begin{array}{l}\text { Local well } \\
\text { identifier }\end{array}$} & \multirow[b]{2}{*}{$\begin{array}{l}\text { Sample } \\
\text { date }\end{array}$} & \multirow[b]{2}{*}{ Time } & \multirow[b]{2}{*}{$\begin{array}{c}\text { Aquifer } \\
\text { type }\end{array}$} & \multirow[b]{2}{*}{ Site type } & \multirow[b]{2}{*}{$\begin{array}{l}\text { Depth } \\
\text { (feet) }\end{array}$} & \multicolumn{3}{|c|}{ Land cover ${ }^{1 / 2}$} & \multirow[b]{2}{*}{$\begin{array}{c}\text { Sample } \\
\text { volume } \\
\text { (liters) }\end{array}$} \\
\hline & & & & & & & $\begin{array}{l}\text { Percentage } \\
\text { urban }\end{array}$ & $\begin{array}{l}\text { Percentage } \\
\text { agricultural }\end{array}$ & $\begin{array}{l}\text { Percentage } \\
\text { forested }\end{array}$ & \\
\hline 394749077024401 & AD 770 & 9/14/00 & 900 & C & Other & -- & 0 & 100 & 0 & 999 \\
\hline 394756077362501 & FR 815 & 9/18/00 & 1330 & C & Restaurant & -- & 0 & 92 & 8 & 999 \\
\hline 395808076191801 & LN 2100 & $12 / 14 / 00$ & 1000 & C & Restaurant & 100 & 0 & 99 & 1 & 999 \\
\hline 395945076030301 & LN 2101 & $1 / 2 / 01$ & 1400 & C & Restaurant & 110 & 5 & 92 & 3 & 999 \\
\hline 400103077315901 & FR $\quad 817$ & $11 / 21 / 00$ & 930 & C & Store & -- & 10 & 87 & 1 & 200 \\
\hline 400136078265101 & BD 655 & $10 / 2 / 00$ & 1030 & C & Store & 500 & 3 & 59 & 36 & 382 \\
\hline 400223076082501 & LN 2099 & $12 / 5 / 00$ & 1430 & C & Restaurant & 600 & 3 & 97 & 0 & 757 \\
\hline 400328077284201 & CU 929 & $9 / 18 / 00$ & 1030 & C & Restaurant & 700 & 17 & 77 & 4 & 999 \\
\hline 400525076224601 & LN 2102 & $1 / 16 / 01$ & 1130 & C & Store & -- & 3 & 97 & 0 & 999 \\
\hline 400852077190001 & CU 931 & $10 / 12 / 00$ & 1000 & C & Roadside rest stop & 120 & 8 & 42 & 49 & 999 \\
\hline 400926077455001 & FR 816 & $10 / 16 / 00$ & 900 & C & Restaurant & 300 & 0 & 100 & 0 & 999 \\
\hline 401512076430201 & DA 831 & $10 / 4 / 00$ & 1100 & C & Other & -- & 0 & 55 & 37 & 416 \\
\hline 401709076255501 & LB 1171 & $11 / 15 / 00$ & 1200 & C & Golf course & 150 & 0 & 96 & 2 & 999 \\
\hline 401749078230201 & BA 541 & $9 / 26 / 00$ & 1630 & C & Store & 278 & 0 & 100 & 0 & 378 \\
\hline 402027076182601 & LB 1172 & $2 / 7 / 01$ & 1100 & C & Restaurant & -- & 0 & 100 & 0 & 999 \\
\hline 402055076003901 & BE 1706 & $11 / 13 / 00$ & 1030 & C & Park & 180 & 3 & 72 & 16 & 673 \\
\hline 402905075501401 & BE 1710 & $12 / 7 / 00$ & 1135 & C & Store & 230 & 2 & 89 & 9 & 999 \\
\hline 403011075411201 & BE 1709 & $12 / 7 / 00$ & 845 & C & Fire department & -- & 13 & 36 & 50 & 999 \\
\hline 403518077141001 & JU 372 & $10 / 18 / 00$ & 930 & C & Store & 125 & 0 & 76 & 24 & 999 \\
\hline 403543078160201 & BA 540 & $9 / 26 / 00$ & 1130 & C & Golf course & -- & 2 & 67 & 1 & 999 \\
\hline 404104075204201 & NP 819 & $1 / 30 / 01$ & 1130 & c & Other & -- & 9 & 53 & 36 & 999 \\
\hline 404700077493001 & CE 685 & $9 / 20 / 00$ & 1100 & C & Restaurant & 273 & 0 & 97 & 3 & 999 \\
\hline 404706077453701 & CE 396 & $11 / 30 / 00$ & 1030 & C & Other & -- & 2 & 46 & & 189 \\
\hline 405619076591501 & UN 204 & $10 / 23 / 00$ & 900 & C & Other & 50 & 7 & 90 & 2 & 999 \\
\hline 410453077284801 & $\mathrm{CN} \quad 444$ & $11 / 16 / 00$ & 1030 & C & Store & -- & 2 & 74 & 24 & 454 \\
\hline 394332076455401 & YO 1214 & $9 / 13 / 00$ & 1300 & $\mathrm{CR}$ & Store & 200 & 0 & 91 & 8 & 1,003 \\
\hline 394341076270501 & YO 1215 & 9/13/00 & 1030 & $\mathrm{CR}$ & Store & -- & 22 & 70 & 6 & 537 \\
\hline 394609076280101 & YO 1220 & $10 / 10 / 00$ & 1000 & $\mathrm{CR}$ & Store & 125 & 0 & 81 & 19 & 999 \\
\hline 394628076533801 & YO 1217 & $9 / 28 / 00$ & 1200 & $\mathrm{CR}$ & Campground & 285 & 0 & 58 & 42 & 999 \\
\hline 394639075515801 & CH 6180 & $11 / 6 / 00$ & 1000 & $\mathrm{CR}$ & Church & -- & 7 & 39 & 52 & 378 \\
\hline 394711076042801 & LN 2097 & 9/19/00 & 1030 & $\mathrm{CR}$ & Campground & -- & 0 & 48 & 50 & 999 \\
\hline 394803076023501 & CH 6176 & $10 / 11 / 00$ & 900 & $\mathrm{CR}$ & Campground & 330 & 0 & 0 & 46 & 999 \\
\hline
\end{tabular}


Appendix 1. Noncommunity supply well information for Pennsylvania-Continued

[USGS, U.S. Geological Survey; Aquifer type codes: C = Carbonate, CR = Crystalline, S = Siliciclastic; U, Unconsolidated; --, no data]

\begin{tabular}{|c|c|c|c|c|c|c|c|c|c|c|}
\hline \multirow[b]{2}{*}{$\begin{array}{l}\text { USGS site } \\
\text { identification } \\
\text { number }\end{array}$} & \multirow[b]{2}{*}{$\begin{array}{l}\text { Local well } \\
\text { identifier }\end{array}$} & \multirow[b]{2}{*}{$\begin{array}{c}\text { Sample } \\
\text { date }\end{array}$} & \multirow[b]{2}{*}{ Time } & \multirow[b]{2}{*}{$\begin{array}{l}\text { Aquifer } \\
\text { type }\end{array}$} & \multirow[b]{2}{*}{ Site type } & \multirow[b]{2}{*}{$\begin{array}{l}\text { Depth } \\
\text { (feet) }\end{array}$} & \multicolumn{3}{|c|}{ Land cover ${ }^{1}{ }^{\prime} 2$} & \multirow[b]{2}{*}{$\begin{array}{c}\text { Sample } \\
\text { volume } \\
\text { (liters) }\end{array}$} \\
\hline & & & & & & & $\begin{array}{l}\text { Percentage } \\
\text { urban }\end{array}$ & $\begin{array}{l}\text { Percentage } \\
\text { agricultural }\end{array}$ & $\begin{array}{c}\text { Percentage } \\
\text { forested }\end{array}$ & \\
\hline 394837075452101 & CH 5999 & $12 / 11 / 00$ & 1000 & CR & Municipal building & 322 & 5 & 81 & 11 & 999 \\
\hline 394942076372701 & YO 1219 & $9 / 27 / 00$ & 1130 & $\mathrm{CR}$ & Industry & -- & 0 & 98 & 2 & 999 \\
\hline 395206076133601 & LN 2098 & $9 / 11 / 00$ & 1300 & $\mathrm{CR}$ & Restaurant & -- & 6 & 94 & 0 & 999 \\
\hline 395302075244601 & $\mathrm{DE} \quad 740$ & $2 / 8 / 01$ & 1430 & $\mathrm{CR}$ & Community swimming pool & 15 & 4 & 69 & 27 & 757 \\
\hline 395419076452001 & YO 771 & $9 / 6 / 00$ & 1100 & $\mathrm{CR}$ & Campground & 207 & 0 & 74 & 22 & 999 \\
\hline 395455075582401 & $\mathrm{CH} 6177$ & $11 / 29 / 00$ & 1100 & CR & Golf course & 325 & 0 & 68 & 32 & 416 \\
\hline 395523076371101 & YO 1216 & $9 / 11 / 00$ & 900 & $\mathrm{CR}$ & Community swimming pool & 300 & 2 & 89 & 9 & 810 \\
\hline 395532076270401 & YO 1221 & $10 / 25 / 00$ & 900 & CR & Campground & 144 & 0 & 30 & 70 & 999 \\
\hline 395608076042901 & LN 2103 & $12 / 11 / 00$ & 1330 & CR & Store & -- & 0 & 96 & 3 & 999 \\
\hline 395655075262301 & $\mathrm{DE} \quad 549$ & $2 / 8 / 01$ & 1100 & $\mathrm{CR}$ & Park & -- & 0 & 5 & 95 & 568 \\
\hline 395946075395701 & CH 5994 & $12 / 21 / 00$ & 1200 & $\mathrm{CR}$ & Campground & -- & 0 & 25 & 75 & 999 \\
\hline 395946076325901 & YO 690 & $9 / 28 / 00$ & 1700 & $\mathrm{CR}$ & Park & 90 & 3 & 66 & 31 & 1,010 \\
\hline 395953075284501 & $\mathrm{CH} 6000$ & $12 / 14 / 00$ & 1430 & $\mathrm{CR}$ & Golf course & 160 & 11 & 14 & 58 & 999 \\
\hline 400144075503001 & $\mathrm{CH} 5993$ & $12 / 18 / 00$ & 930 & $\mathrm{CR}$ & Park & 400 & 0 & 0 & 100 & 663 \\
\hline 400309075152901 & PH 804 & $10 / 17 / 00$ & 900 & $\mathrm{CR}$ & Other & 360 & 0 & 0 & 77 & 999 \\
\hline 400321075531301 & $\mathrm{CH} 6178$ & $10 / 3 / 00$ & 1000 & $\mathrm{CR}$ & Campground & 333 & 0 & 3 & 94 & 1,022 \\
\hline 400614075483701 & $\mathrm{CH} 6179$ & $10 / 3 / 00$ & 1230 & $\mathrm{CR}$ & Store & 98 & 0 & 23 & 77 & 378 \\
\hline 401216074541201 & BK 2995 & $12 / 19 / 00$ & 1130 & $\mathrm{CR}$ & Park & -- & 11 & 54 & 34 & 416 \\
\hline 402101077211801 & PE 845 & $1 / 9 / 01$ & 1100 & $S$ & Campground & 510 & 5 & 14 & 69 & 999 \\
\hline 402339078053401 & HU 425 & $12 / 4 / 00$ & 1000 & $S$ & Park & -- & 0 & 31 & 69 & 999 \\
\hline 402917078165001 & BA 542 & $10 / 16 / 00$ & 1300 & S & Park & 385 & 0 & 53 & 34 & 999 \\
\hline 403045076062101 & BE 1711 & $1 / 29 / 01$ & 1100 & $S$ & Hotel & 325 & 16 & 77 & 5 & 757 \\
\hline 405722077421601 & CE 395 & $9 / 25 / 00$ & 1100 & S & Campground & 136 & 0 & 34 & 66 & 1,007 \\
\hline 413933076152901 & BR 852 & $1 / 24 / 01$ & 1230 & $U$ & Industry & 136 & 2 & 70 & 27 & 999 \\
\hline 414554076245301 & BR 851 & $1 / 17 / 01$ & 1500 & $U$ & Industry & 101 & 22 & 76 & 2 & 568 \\
\hline 414617076435801 & BR 853 & $1 / 18 / 01$ & 1100 & $U$ & School & 58 & 0 & 80 & 20 & 999 \\
\hline 415638080281801 & ER 2502 & $1 / 31 / 01$ & 1500 & $U$ & Restaurant & 12 & 14 & 32 & 42 & 398 \\
\hline 415648080281301 & ER 2503 & $2 / 1 / 01$ & 1100 & $U$ & Church & 36 & 14 & 32 & 42 & 999 \\
\hline
\end{tabular}

${ }^{1}$ Combined urban, agricultural, and forested land-cover percentages may total less than 100 percent at a site due to "other" land-cover category not shown.

${ }^{2}$ Land-cover percentages are within a 1,500-foot radius of the well. 
Appendix 2. Water-quality data for noncommunity supply wells in Pennsylvania

[USGS, U.S. Geological Survey; CFU = Colony forming units; PFU = Plaque forming units; plus symbol (+) indicates a detection of $H$. pylori; >, greater than; $<$, less than; --, no data; ; ${ }^{\circ} \mathrm{C}$, degrees Celsius; mg/L, milligrams per liter]

\begin{tabular}{|c|c|c|c|c|c|c|c|c|c|c|c|c|c|}
\hline \multirow[b]{3}{*}{$\begin{array}{c}\text { USGS site } \\
\text { identification } \\
\text { number }\end{array}$} & \multirow[b]{3}{*}{$\begin{array}{c}\text { Sample } \\
\text { date }\end{array}$} & \multicolumn{12}{|c|}{ USGS parameter code and description } \\
\hline & & 00010 & 00400 & 00300 & 00095 & 31505 & 50468 & 99602 & 90915 & 99601 & 90911 & 90912 & 90910 \\
\hline & & $\begin{array}{c}\text { Water } \\
\text { tempera- } \\
\text { ture } \\
\left({ }^{\circ} \mathrm{C}\right)\end{array}$ & $\begin{array}{c}\mathrm{pH} \\
\text { (standard } \\
\text { units) }\end{array}$ & $\begin{array}{c}\text { Dis- } \\
\text { solved } \\
\text { oxygen } \\
(\mathrm{mg} / \mathrm{L})\end{array}$ & $\begin{array}{c}\text { Specific } \\
\text { conductance } \\
\text { (micro- } \\
\text { siemens per } \\
\text { centimeter) }\end{array}$ & $\begin{array}{c}\text { Total } \\
\text { coliform } \\
\text { (colonies } \\
\text { per } 100 \\
\text { milliliters) }\end{array}$ & $\begin{array}{c}\text { Escherichia } \\
\text { coli } \\
\text { (colonies } \\
\text { per } 100 \\
\text { milliliters) }\end{array}$ & $\begin{array}{c}\text { Helicobacter } \\
\text { pylori } \\
\text { (cells per } \\
\text { milliliter) }\end{array}$ & $\begin{array}{c}\text { Clostridium } \\
\text { perfringens } \\
\text { (CFU } \\
\text { per } 100 \\
\text { milliliters) }\end{array}$ & $\begin{array}{c}\text { Entero- } \\
\text { cocci } \\
\text { (CFU } \\
\text { per 100 } \\
\text { milliliters) }\end{array}$ & $\begin{array}{l}\text { Coliphage, } \\
\text { somatic } \\
\text { (PFU per } \\
100 \text { liters) }\end{array}$ & $\begin{array}{c}\text { Coliphage, } \\
\text { male } \\
\text { specific } \\
\text { (PFU per } \\
100 \text { liters) }\end{array}$ & $\begin{array}{c}\text { Total } \\
\text { culturable } \\
\text { virus } \\
\text { (PFU per } \\
100 \text { liters) }\end{array}$ \\
\hline 394749077024401 & $9 / 14 / 00$ & 15.2 & 7.3 & 3.9 & 409 & 41 & $<1$ & $<4$ & $<0.5$ & $<1$ & $<10$ & $<10$ & $<0.20$ \\
\hline 394756077362501 & $9 / 18 / 00$ & 16.8 & 7.1 & 7.7 & 862 & 10 & 1 & $>4(+)$ & 1 & $<1$ & $<10.4$ & $<10.4$ & $<.21$ \\
\hline 395808076191801 & $12 / 14 / 00$ & 11.9 & 6.9 & 7.6 & 785 & $<1$ & $<1$ & $<4$ & $<.5$ & $<1$ & $<9.5$ & $<9.5$ & $<.21$ \\
\hline 395945076030301 & $1 / 2 / 01$ & 7.9 & 7.6 & 6.6 & 458 & $<1$ & $<1$ & $<4$ & $<.5$ & $<1$ & $<10.06$ & $<10.06$ & $<.20$ \\
\hline 400103077315901 & $11 / 21 / 00$ & 12.3 & 7.6 & 7.9 & 513 & $<1$ & $<1$ & $<4$ & $<.5$ & $<1$ & $<13.2$ & $<13.2$ & $<.27$ \\
\hline 400136078265101 & $10 / 2 / 00$ & 14.2 & 7.1 & 1.8 & 764 & $<1$ & $<1$ & $<4$ & $<.5$ & $<1$ & $<26.6$ & $<26.6$ & $<.53$ \\
\hline 400223076082501 & $12 / 5 / 00$ & 12.0 & 7.4 & 7.2 & 678 & $<1$ & $<1$ & $<4$ & $<.5$ & $<1$ & $<12.3$ & $<12.3$ & $<.27$ \\
\hline 400328077284201 & $9 / 18 / 00$ & 17.9 & 7.4 & 6.1 & 279 & 21 & 2 & $<4$ & $<.5$ & $<1$ & $<9.8$ & $<9.8$ & $<.20$ \\
\hline 400525076224601 & $1 / 16 / 01$ & 12.3 & 7.4 & .4 & 687 & $<1$ & $<1$ & $<4$ & $<.5$ & $<1$ & $<9.45$ & $<9.45$ & $<.20$ \\
\hline 400852077190001 & $10 / 12 / 00$ & 13.7 & 6.8 & 5.1 & 1300 & 6 & $<1$ & $<4$ & $<.5$ & $<1$ & $<10$ & $<10$ & $<.20$ \\
\hline 400926077455001 & $10 / 16 / 00$ & 12.5 & 3.3 & -- & 888 & $<1$ & $<1$ & $<4$ & $<.5$ & $<1$ & $<9.9$ & $<9.9$ & $<.20$ \\
\hline 401512076430201 & $10 / 4 / 00$ & 15.1 & 6.9 & 5.2 & 775 & 53 & 4 & $<4$ & $<.5$ & $<1$ & $<24.3$ & $<24.3$ & $<.49$ \\
\hline 401709076255501 & $11 / 15 / 00$ & 12.0 & 7.3 & 7.8 & 642 & 1 & $<1$ & $<4$ & $<.5$ & $<1$ & $<10$ & $<10$ & $<.21$ \\
\hline 401749078230201 & $9 / 26 / 00$ & 13.9 & 7.0 & 8.3 & 825 & 9 & $<1$ & $<4$ & $<.5$ & $<1$ & $<26.6$ & $<26.6$ & $<.52$ \\
\hline 402027076182601 & $2 / 7 / 01$ & 11.6 & 7.4 & 8.2 & 552 & $<1$ & $<1$ & $<4$ & $<.5$ & $<1$ & $<9.81$ & $<9.81$ & $<.21$ \\
\hline 402055076003901 & $11 / 13 / 00$ & 12.2 & 7.4 & 2.1 & 501 & 5 & 1 & $<4$ & .5 & $<1$ & 61 & $<15.3$ & $<.30$ \\
\hline 402905075501401 & $12 / 7 / 00$ & 10.5 & 7.5 & 8.3 & 580 & $<1$ & $<1$ & $<4$ & $<.5$ & $<1$ & $<9.6$ & $<9.6$ & $<.21$ \\
\hline 403011075411201 & $12 / 7 / 00$ & 11.1 & 8.2 & 7.2 & 278 & $<1$ & $<1$ & $<4$ & $<.5$ & $<1$ & $<9.5$ & $<9.5$ & $<.02$ \\
\hline 403518077141001 & $10 / 18 / 00$ & 11.8 & 7.3 & .2 & 534 & $>200$ & 56 & $<4$ & 1.5 & 69.7 & 525.5 & 189.2 & 51.99 \\
\hline 403543078160201 & $9 / 26 / 00$ & 11.7 & 6.9 & 3.3 & 875 & 70 & $<1$ & $<4$ & $<.5$ & 1 & 9.4 & $<9.4$ & $<.21$ \\
\hline 404104075204201 & $1 / 30 / 01$ & 10.9 & 7.5 & 6.0 & 574 & $<1$ & $<1$ & $<4$ & $<.5$ & $<1$ & $<9.91$ & $<9.91$ & $<.21$ \\
\hline 404700077493001 & $9 / 20 / 00$ & 12.9 & 7.1 & 6.6 & 1365 & $<1$ & $<1$ & $<4$ & $<.5$ & $<1$ & $<10$ & $<10$ & $<.21$ \\
\hline 404706077453701 & $11 / 30 / 00$ & 11.8 & 7.5 & 11.7 & 298 & $>200$ & 27 & $>4(+)$ & 3 & 22.2 & 99.5 & 50 & 18.3 \\
\hline 405619076591501 & $10 / 23 / 00$ & 13.3 & 6.9 & 4.4 & 836 & 24 & $<1$ & $<4$ & $<.5$ & 2 & $<9.7$ & $<9.7$ & $<.21$ \\
\hline
\end{tabular}


Appendix 2. Water-quality data for noncommunity supply wells in Pennsylvania-Continued

[USGS, U.S. Geological Survey; CFU = Colony forming units; PFU = Plaque forming units; plus symbol (+) indicates a detection of $H$. pylori; >, greater than; $<$, less than; --, no data; ; ${ }^{\circ} \mathrm{C}$, degrees Celsius; mg/L, milligrams per liter]

\begin{tabular}{|c|c|c|c|c|c|c|c|c|c|c|c|c|c|}
\hline \multirow[b]{3}{*}{$\begin{array}{c}\text { USGS site } \\
\text { identification } \\
\text { number }\end{array}$} & \multirow[b]{3}{*}{$\begin{array}{l}\text { Sample } \\
\text { date }\end{array}$} & \multicolumn{12}{|c|}{ USGS parameter code and description } \\
\hline & & 00010 & 00400 & 00300 & 00095 & 31505 & 50468 & 99602 & 90915 & 99601 & 90911 & 90912 & 90910 \\
\hline & & $\begin{array}{c}\text { Water } \\
\text { tempera- } \\
\text { ture } \\
\left({ }^{\circ} \mathrm{C}\right)\end{array}$ & $\begin{array}{c}\mathrm{pH} \\
\text { (standard } \\
\text { units) }\end{array}$ & $\begin{array}{c}\text { Dis- } \\
\text { solved } \\
\text { oxygen } \\
(\mathrm{mg} / \mathrm{L})\end{array}$ & $\begin{array}{c}\text { Specific } \\
\text { conductance } \\
\text { (micro- } \\
\text { siemens per } \\
\text { centimeter) }\end{array}$ & $\begin{array}{l}\text { Total } \\
\text { coliform } \\
\text { (colonies } \\
\text { per 100 } \\
\text { milliliters) }\end{array}$ & $\begin{array}{c}\text { Escherichia } \\
\text { coli } \\
\text { (colonies } \\
\text { per } 100 \\
\text { milliliters) }\end{array}$ & $\begin{array}{c}\text { Helicobacter } \\
\text { pylori } \\
\text { (cells per } \\
\text { milliliter) }\end{array}$ & $\begin{array}{c}\text { Clostridium } \\
\text { perfringens } \\
\text { (CFU } \\
\text { per } 100 \\
\text { milliliters) }\end{array}$ & $\begin{array}{c}\text { Entero- } \\
\text { cocci } \\
\text { (CFU } \\
\text { per 100 } \\
\text { milliliters) }\end{array}$ & $\begin{array}{l}\text { Coliphage, } \\
\text { somatic } \\
\text { (PFU per } \\
100 \text { liters) }\end{array}$ & $\begin{array}{c}\text { Coliphage, } \\
\text { male } \\
\text { specific } \\
\text { (PFU per } \\
100 \text { liters) }\end{array}$ & $\begin{array}{c}\text { Total } \\
\text { culturable } \\
\text { virus } \\
\text { (PFU per } \\
100 \text { liters) }\end{array}$ \\
\hline 410453077284801 & $11 / 16 / 00$ & 11.9 & 7.1 & 1.0 & 924 & 200 & 2 & $<4$ & 1 & 6.4 & $<22$ & $<22$ & $<0.44$ \\
\hline 394332076455401 & $9 / 13 / 00$ & 14.5 & 5.0 & 9.3 & 118 & $<1$ & $<1$ & $<4$ & $<.5$ & $<1$ & $<9.8$ & $<9.8$ & $<.20$ \\
\hline 394341076270501 & $9 / 13 / 00$ & 17.5 & 5.8 & 5.3 & 358 & $<1$ & $<1$ & $<4$ & $<.5$ & $<1$ & $<18.4$ & $<18.4$ & $<.38$ \\
\hline 394609076280101 & $10 / 10 / 00$ & 6.8 & 5.0 & 1.4 & 679 & $<1$ & $<1$ & $<4$ & $<.5$ & $<1$ & $<9.5$ & $<9.5$ & $<.20$ \\
\hline 394628076533801 & $9 / 28 / 00$ & 12.4 & 5.7 & 7.7 & 134 & 110 & $<1$ & $<4$ & 1 & 8.7 & $<10.7$ & $<10.7$ & $<.21$ \\
\hline 394639075515801 & $11 / 6 / 00$ & 15.0 & 6.2 & 6.3 & 154 & $>200$ & $<1$ & $<4$ & $<.5$ & $<1$ & $<27.7$ & $<27.7$ & $<.54$ \\
\hline 394711076042801 & $9 / 19 / 00$ & 14.6 & 5.7 & 8.5 & 50 & 1 & $<1$ & $<4$ & $<.5$ & $<1$ & $<10.3$ & $<10.3$ & $<.20$ \\
\hline 394803076023501 & $10 / 11 / 00$ & 11.1 & 6.7 & 5.9 & 128 & $<1$ & $<1$ & $<4$ & $<.5$ & $<1$ & $<10$ & $<10$ & $<.21$ \\
\hline 394837075452101 & $12 / 11 / 00$ & 12.3 & 6.7 & .1 & 227 & $<1$ & $<1$ & $<4$ & $<.5$ & $<1$ & $<9$ & $<9$ & $<.21$ \\
\hline 394942076372701 & $9 / 27 / 00$ & 15.9 & 5.1 & 1.7 & 161 & $<1$ & $<1$ & $<4$ & $<.5$ & $<1$ & $<10$ & $<10$ & $<.20$ \\
\hline 395206076133601 & $9 / 11 / 00$ & 14.0 & 6.0 & 7.1 & -- & $<1$ & $<1$ & $<4$ & $<.5$ & $<1$ & $<9.9$ & $<9.9$ & $<.21$ \\
\hline 395302075244601 & $2 / 8 / 01$ & 9.6 & 5.8 & 3.9 & 224 & 41 & $<1$ & $<4$ & $<.5$ & 1 & $<13.3$ & $<13.3$ & $<.27$ \\
\hline 395419076452001 & $9 / 6 / 00$ & 12.5 & 6.3 & 7.1 & 182 & $<1$ & $<1$ & $<4$ & $<.5$ & $<1$ & $<9.5$ & $<9.5$ & $<.2$ \\
\hline 395455075582401 & $11 / 29 / 00$ & 12.9 & 5.4 & 7.7 & 244 & 2 & $<1$ & $<4$ & $<.5$ & $<1$ & $<23$ & $<23$ & $<.49$ \\
\hline 395523076371101 & 9/11/00 & 14.6 & 6.1 & 2.5 & -- & 3 & $<1$ & $<4$ & 1.5 & 2 & $<12.2$ & $<12.2$ & $<.26$ \\
\hline 395532076270401 & $10 / 25 / 00$ & 16.2 & 5.1 & 7.3 & 75 & $<1$ & $<1$ & $<4$ & $<.5$ & $<1$ & $<10.2$ & $<10.2$ & $<.20$ \\
\hline 395608076042901 & $12 / 11 / 00$ & 11.9 & 5.2 & 8.8 & 308 & $<1$ & $<1$ & $<4$ & $<.5$ & $<1$ & $<9.7$ & $<9.7$ & $<.21$ \\
\hline 395655075262301 & $2 / 8 / 01$ & 9.9 & 6.3 & 7.1 & 169 & $<1$ & $<1$ & $<4$ & .5 & $<1$ & $<17.9$ & $<17.9$ & $<.35$ \\
\hline 395946075395701 & $12 / 21 / 00$ & 11.9 & 5.8 & 6.9 & 89 & 15 & $<1$ & $<4$ & $<.5$ & $<1$ & $<9.75$ & $<9.75$ & .21 \\
\hline 395946076325901 & $9 / 28 / 00$ & 12.3 & 6.6 & .2 & 126 & $<1$ & $<1$ & $<4$ & $<.5$ & $<1$ & $<9.5$ & $<9.5$ & $<.19$ \\
\hline 395953075284501 & $12 / 14 / 00$ & 10.4 & 6.1 & 9.9 & 306 & $<1$ & $<1$ & $<4$ & $<.5$ & $<1$ & $<9.8$ & $<9.8$ & $<.21$ \\
\hline 400144075503001 & $12 / 18 / 00$ & 11.2 & 7.0 & 2.4 & 338 & $<1$ & $<1$ & $>4(+)$ & $<.5$ & $<1$ & $<14.5$ & $<14.5$ & $<.29$ \\
\hline 400309075152901 & $10 / 17 / 00$ & 13.3 & 6.8 & 5.2 & 153 & 83 & $<1$ & $<4$ & $<.5$ & $<1$ & $<9.1$ & $<9.1$ & $<.21$ \\
\hline 400321075531301 & $10 / 3 / 00$ & 10.9 & 5.9 & 5.7 & 23 & 3 & $<1$ & $>4(+)$ & $<.5$ & $<1$ & $<9.3$ & $<9.3$ & $<.21$ \\
\hline
\end{tabular}


Appendix 2. Water-quality data for noncommunity supply wells in Pennsylvania-Continued

USGS, U.S. Geological Survey; CFU = Colony forming units; PFU = Plaque forming units; plus symbol (+) indicates a detection of $H$. pylori; >, greater than; $<$, less than; --, no data; ;C, degrees Celsius; mg/L, milligrams per liter]

\begin{tabular}{|c|c|c|c|c|c|c|c|c|c|c|c|c|c|}
\hline \multirow[b]{3}{*}{$\begin{array}{c}\text { USGS site } \\
\text { identification } \\
\text { number }\end{array}$} & \multirow[b]{3}{*}{$\begin{array}{c}\text { Sample } \\
\text { date }\end{array}$} & \multicolumn{12}{|c|}{ USGS parameter code and description } \\
\hline & & 00010 & 00400 & 00300 & 00095 & 31505 & 50468 & 99602 & 90915 & 99601 & 90911 & 90912 & 90910 \\
\hline & & $\begin{array}{c}\text { Water } \\
\text { tempera- } \\
\text { ture } \\
\left({ }^{\circ} \mathrm{C}\right)\end{array}$ & $\begin{array}{c}\mathrm{pH} \\
\text { (standard } \\
\text { units) }\end{array}$ & $\begin{array}{c}\text { Dis- } \\
\text { solved } \\
\text { oxygen } \\
(\mathrm{mg} / \mathrm{L})\end{array}$ & $\begin{array}{c}\text { Specific } \\
\text { conductance } \\
\text { (micro- } \\
\text { siemens per } \\
\text { centimeter) }\end{array}$ & $\begin{array}{c}\text { Total } \\
\text { coliform } \\
\text { (colonies } \\
\text { per } 100 \\
\text { milliliters) }\end{array}$ & $\begin{array}{c}\text { Escherichia } \\
\text { coli } \\
\text { (colonies } \\
\text { per } 100 \\
\text { milliliters) }\end{array}$ & $\begin{array}{c}\text { Helicobacter } \\
\text { pylori } \\
\text { (cells per } \\
\text { milliliter) }\end{array}$ & $\begin{array}{c}\text { Clostridium } \\
\text { perfringens } \\
\text { (CFU } \\
\text { per } 100 \\
\text { milliliters) }\end{array}$ & $\begin{array}{c}\text { Entero- } \\
\text { cocci } \\
\text { (CFU } \\
\text { per 100 } \\
\text { milliliters) }\end{array}$ & $\begin{array}{c}\text { Coliphage, } \\
\text { somatic } \\
\text { (PFU per } \\
100 \text { liters) }\end{array}$ & $\begin{array}{c}\text { Coliphage, } \\
\text { male } \\
\text { specific } \\
\text { (PFU per } \\
100 \text { liters) }\end{array}$ & $\begin{array}{c}\text { Total } \\
\text { culturable } \\
\text { virus } \\
\text { (PFU per } \\
100 \text { liters) }\end{array}$ \\
\hline 400614075483701 & $10 / 3 / 00$ & 16.9 & 5.7 & 7.4 & 316 & 38 & $<1$ & $<4$ & $<0.5$ & $<1$ & $<25.8$ & $<25.8$ & $<0.56$ \\
\hline 401216074541201 & $12 / 19 / 00$ & 13.0 & 5.6 & -- & 206 & 43 & $<1$ & $<4$ & $<.5$ & $<1$ & $<23.2$ & $<23.2$ & $<.50$ \\
\hline 402101077211801 & $1 / 9 / 01$ & 11.3 & 7.7 & 3.6 & 250 & $<1$ & $<1$ & $<4$ & $<.5$ & $<1$ & $<9.8$ & $<9.8$ & $<.21$ \\
\hline 402339078053401 & $12 / 4 / 00$ & 11.6 & 7.0 & 2.9 & 234 & $<1$ & $<1$ & $<4$ & $<.5$ & $<1$ & $<9.8$ & $<9.8$ & .21 \\
\hline 402917078165001 & $10 / 16 / 00$ & 13.6 & 3.2 & 5.5 & 345 & $<1$ & $<1$ & $<4$ & $<.5$ & $<1$ & $<9.4$ & $<9.4$ & $<.20$ \\
\hline 403045076062101 & $1 / 29 / 01$ & 10.2 & 6.9 & 2.0 & 278 & 1 & $<1$ & $<4$ & .5 & $<1$ & $<12.15$ & $<12.15$ & $<.27$ \\
\hline 405722077421601 & $9 / 25 / 00$ & 12.7 & 7.1 & 2.6 & 422 & 3 & $<1$ & $<4$ & $<.5$ & $<1$ & $<10$ & $<10$ & $<.20$ \\
\hline 413933076152901 & $1 / 24 / 01$ & 11.2 & 7.3 & 1.3 & 712 & $<1$ & $<1$ & $<4$ & $<.5$ & $<1$ & 182 & 30 & 33.4 \\
\hline 414554076245301 & $1 / 17 / 01$ & 11.0 & 7.5 & .1 & 463 & $<1$ & $<1$ & $<4$ & $<.5$ & $<1$ & $<15.8$ & $<15.8$ & $<.37$ \\
\hline 414617076435801 & $1 / 18 / 01$ & 10.2 & 6.9 & 2.5 & 382 & $<1$ & $<1$ & $<4$ & $<.5$ & $<1$ & $<9.85$ & $<9.85$ & $<.20$ \\
\hline 415638080281801 & $1 / 31 / 01$ & 9.9 & 7.0 & .1 & 903 & $<1$ & $<1$ & $<4$ & $<.5$ & $<1$ & $<24.6$ & $<24.6$ & $<.5$ \\
\hline 415648080281301 & $2 / 1 / 01$ & 6.3 & 8.1 & 4.0 & 249 & 10 & $<1$ & $<4$ & $<.5$ & $<1$ & $<9.2$ & $<9.2$ & $<.21$ \\
\hline
\end{tabular}


